\title{
Targeted delivery of a designed sTRAIL mutant results in superior apoptotic activity towards EGFR-positive tumor cells
}

\author{
Edwin Bremer - Marco de Bruyn • \\ Douwe F. Samplonius - Theo Bijma - Bram ten Cate • \\ Lou F. M. H. de Leij • Wijnand Helfrich
}

Received: 3 August 2007 /Revised: 19 February 2008 / Accepted: 28 February 2008 / Published online: 27 May 2008

(C) The Author(s) 2008

\begin{abstract}
Previously, we have shown that epidermal growth factor receptor (EGFR)-selective delivery of soluble tumor necrosis factor-related apoptosis-inducing ligand (sTRAIL), by genetic fusion to antibody fragment scFv425, enhances the tumor-selective pro-apoptotic activity of sTRAIL. Insight into the respective contribution of the agonistic receptors TRAIL-R1 and TRAIL-R2 to TRAILinduced apoptosis may provide a rational approach to further optimize TRAIL-based therapy. Recently, this issue has been investigated using sTRAIL mutants designed to selectively bind to either receptor. However, the relative contribution of the respective TRAIL receptors, in particular TRAIL-R1, in TRAIL signaling is still unresolved. Here, we fused scFv425 to designed sTRAIL mutant sTRAILmR1-5, reported to selectively activate TRAIL$\mathrm{R} 1$, and investigated the therapeutic apoptotic activity of this novel fusion protein. EGFR-specific binding of scFv425:sTRAILmR1-5 potently induced apoptosis, which was superior to the apoptotic activity of scFv425:sTRAILwt and a nontargeted MOCK-scFv:sTRAILmR1-5. During cotreatment with cisplatin or the histone deacetylase inhibitor
\end{abstract}

Electronic supplementary material The online version of this article (doi:10.1007/s00109-008-0348-9) contains supplementary material, which is available to authorized users.

Supported by grants from the Dutch Cancer Society (RUG 2002-2668, 2005-3358 and 2007-3784 to W.H.).

E. Bremer · M. de Bruyn • D. F. Samplonius · T. Bijma •

B. ten Cate $\cdot$ L. F. M. H. de Leij $\cdot$ W. Helfrich $(\square)$

Laboratory for Tumor Immunology, Section Medical Biology,

Department of Pathology and Laboratory Medicine,

University Medical Center Groningen,

Hanzeplein 1,

9713 GZ, Groningen, The Netherlands

e-mail: w.helfrich@med.umcg.nl

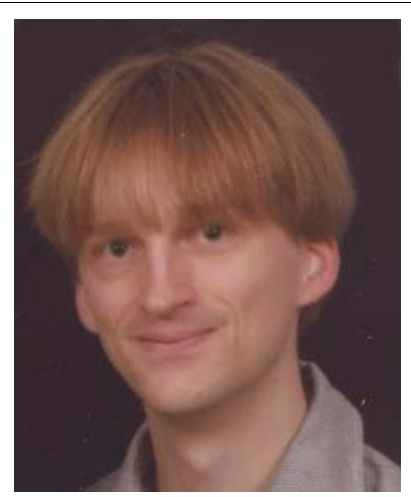

EDWIN BREMER received his $\mathrm{Ph} . \mathrm{D}$. in Medical Sciences from the University of Groningen, the Netherlands. He is presently a post-doctoral Fellow in the laboratory for Tumor Immunology at the University Medical Center Groningen. His research interests include targeted induction of apoptosis by death ligands for cancer therapy.

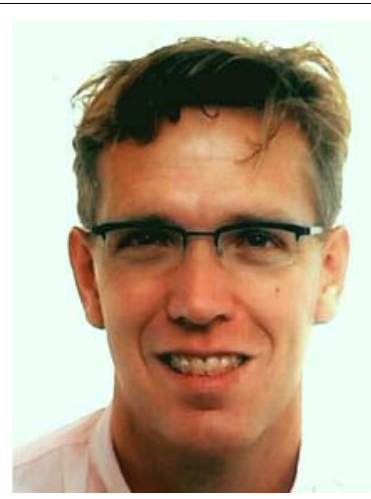

WiJNAND HeLFRICH received his Ph.D. in Medical Sciences from the University of Groningen, the Netherlands. He is presently an Associate Professor of Biomedical Science and Head of the laboratory for Tumor Immunology at the University

Medical Center Groningen, University of Groningen. His research interests include antibody engineering and targeted induction of apoptosis by death ligands for cancer therapy. valproic acid, scFv425:sTRAILmR1-5 retained its superior pro-apoptotic activity compared to scFv425:sTRAILwt. However, in catching-type Enzyme-Linked ImmunoSorbent Assays with TRAIL-R1:Fc and TRAIL-R2:Fc, scFv425:sTRAILmR1-5 was found to not only bind to TRAIL-R1 but also to TRAIL-R2. Binding to TRAIL-R2 also had functional consequences because the apoptotic activity of scFv425:sTRAILmR1-5 was strongly inhibited by a TRAIL-R2 blocking monoclonal antibody. Moreover, 
scFv425:sTRAILmR1-5 retained apoptotic activity upon selective knockdown of TRAIL-R1 using small inhibitory RNA. Collectively, these data indicate that both agonistic TRAIL receptors are functionally involved in TRAIL signaling by scFv425:sTRAILmR1-5 in solid tumor cells. Moreover, the superior target cell-restricted apoptotic activity of scFv425:sTRAILmR1-5 indicates its therapeutic potential for EGFR-positive solid tumors.

Keywords TRAIL · Targeting - EGFR - TRAIL receptor . Mutant $\cdot$ Selective

\section{Introduction}

The Tumor Necrosis Factor-Related Apoptosis-Inducing Ligand (TRAIL) is normally present as a type II transmembrane protein on immune effector cells, such as natural killer (NK) cells. As such, TRAIL is involved in the elimination of, e.g., metastasizing cancer cells $[1,2]$. TRAIL can also be proteolytically cleaved into a homotrimeric soluble form, soluble TRAIL (sTRAIL), that partly retains tumoricidal activity [3, 4]. Several recombinant derivatives of sTRAIL have been generated that all display promising antitumor activity in vitro and in human xenografted tumor mouse models [5-7].

Recently, we and others have demonstrated that the tumor cell specific activity of sTRAIL can be augmented by genetic fusion to a tumor-selective antibody fragment [812]. Antibody fragment-mediated binding of such scFv: sTRAIL fusion proteins to a cell surface-expressed target antigen results in tumor cell accretion and converts soluble TRAIL into membrane-bound TRAIL. Subsequently, agonistic TRAIL receptors are efficiently activated in a monocellular and/or bicellular manner.

TRAIL signals apoptosis by binding to the agonistic receptors TRAIL-R1 and TRAIL-R2 [13-15]. Concomitantly, an intracellular cascade of caspase activation ensues that ultimately results in the apoptotic demise of the cell. These agonistic receptors are characterized by a cytoplasmic region known as the Death Domain, which is critical for signal transduction upon TRAIL-binding. TRAIL can also interact with three antagonistic receptors, TRAIL-R3, TRAIL-R4, and osteoprotegerin. TRAIL-R3 is a phospholipid-anchored receptor that lacks a cytoplasmic domain [14, 16, 17]. TRAIL-R4 has a truncated intracellular domain incapable of transmitting the apoptotic signal [18-20]. Osteoprotegerin is a soluble receptor for TRAIL [21] that is best known for its involvement in bone homeostasis as a soluble receptor for the tumor necrosis factor homolog Receptor Activator for Nuclear Factor K B Ligand (RANKL).

This intricate receptor system, with five distinct receptors that differentially bind and interact with TRAIL, suggests that the outcome of TRAIL signaling is subject to a high degree of regulation [22]. Therefore, insight into the respective contribution of the agonistic receptors TRAIL-R1 and TRAIL-R2 to apoptotic signaling by TRAIL may provide a rational approach to optimize TRAIL therapy for a specific tumor type.

Several laboratories have studied this issue using sTRAIL mutants designed to selectively bind to one of the agonistic TRAIL receptors and not to the antagonistic receptors [23-25]. Using TRAIL-R1 and TRAIL-R2 selective sTRAIL mutants, Kelley et al. ascribed a greater contribution of TRAIL-R2 to TRAIL-apoptotic signaling in solid tumor cells [23]. Similarly, van der Molen et al. reported that selective TRAIL-R2 activation results in enhanced pro-apoptotic activity [24]. On the other hand, MacFarlane et al. concluded that apoptosis signaling was exclusively mediated by TRAIL-R1 in Chronic Lymphocytic Leukemia [25]. Importantly, experimental data in the latter paper indicates that the TRAIL-R1 selective sTRAIL mutant used by Kelley et al. is actually largely inactive. Thus, the exact contribution of TRAIL-R1 and TRAIL-R2 to TRAIL-induced apoptosis remains to be elucidated.

Previously, we have demonstrated that epidermal growth factor receptor (EGFR)-targeted delivery of wild-type sTRAIL, using scFv425:sTRAIL, enhanced the tumorselective binding and activity [10]. Here, we genetically fused antibody fragment scFv425 to sTRAILmR1-5 reported by MacFarlane et al. to selectively activate TRAIL-R1 and investigated the therapeutic apoptotic activity of this novel fusion protein. Fusion protein scFv425:sTRAILmR1-5 showed superior apoptotic activity compared to the corresponding wild-type sTRAIL fusion protein on half of the EGFR-positive solid tumor cell lines tested and showed a nonsignificant trend to higher apoptotic activity on the other cell lines. Furthermore, scFv425:sTRAILmR1-5 showed superior apoptotic activity in comparison to a MOCK-scFv:sTRAILmR1-5 fusion protein, with irrelevant target specificity. However, in contrast to the findings of MacFarlane et al., we found that the sTRAILmR1-5 domain in our scFv425:sTRAILmR1-5 fusion protein also bound to and partly signaled apoptosis via TRAIL-R2. Taken together, EGFR-selective delivery and induction of apoptosis by scFv425:sTRAILmR1-5 is a potentially promising therapeutic approach for EGFR-positive solid tumors.

\section{Materials and methods}

Cell lines

The following cell lines were purchased from the American Type Culture Collection (Manassas, VA, USA): ALL T-cell 
line (Jurkat), Burkitt Lymphoma (Ramos), epidermoid carcinoma (A431), ovarian carcinoma (OVCAR-3), colon carcinoma (WiDr and HT-29), lung carcinoma (A549), renal cell carcinoma (Sk-rc-52), prostate carcinoma (PC-3M), glioblastoma multiforme (A172), and medulloblastoma (HS-683). Jurkat.EGFRvIII was generated as previously described [10]. Renal cell carcinomas (RC21 cells) were generously provided by Prof. Dr. Clemens Löwik (University Medical Center Leiden, Leiden, The Netherlands). All cell lines were cultured at $37^{\circ} \mathrm{C}$ in a humidified $5 \% \mathrm{CO}_{2}$ atmosphere. All cell lines were cultured in RPMI 1640 (Cambrex Bio Science, Verviers, France) supplemented with $10 \%$ fetal calf serum.

\section{Expression of EGFR and TRAIL receptors}

Membrane expression levels of EGFR were analyzed using mAb425. Membrane expression levels of TRAIL receptors $1,2,3$, and 4 , were analyzed by flow cytometry using a TRAIL receptor antibody kit purchased from Alexis (10P's, Breda, The Netherlands). Briefly, cells were harvested, washed using serum-free RPMI, and resuspended in $100 \mu \mathrm{l}$ fresh medium containing the appropriate primary monoclonal antibody $(\mathrm{mAb})$. Specific binding of the primary antibody was detected using a phycoerythrin (PE)-conjugated secondary antibody (DAKO, Glostrup, Denmark). All antibody incubations were performed at $0^{\circ} \mathrm{C}$ for $45 \mathrm{~min}$ and were followed by two washes with serum-free medium.

Recombinant sTRAIL, monoclonal antibodies, and inhibitors

Flag-tagged sTRAIL and secondarily cross linked killer TRAIL (kTRAIL) were both purchased from Alexis. MAb 425 (kindly provided by Merck, Darmstadt, Germany) is a murine immunoglobulin $\mathrm{G} 2 \mathrm{a}$ with high binding affinity for the extracellular domain of EGFR and EGFRvIII. TRAILneutralizing mAb 2E5 was purchased from Alexis (10P's, Breda, The Netherlands). MAb 425 competes with scFv425 for binding to the same epitope. The histone deacetylase inhibitor valproic acid (VPA) was from Sigma-Aldrich (Zwijndrecht, The Netherlands) and was dissolved at $100 \mathrm{mM}$ in $\mathrm{dH}_{2} \mathrm{O}$. The cytostatic drug cisplatin was dissolved at $1 \mathrm{mg} / \mathrm{ml}$ in $0.9 \% \mathrm{NaCl}$. I $\mathrm{KB}$ kinase (IKK) inhibitor wedelolactone was purchased from Sigma-Aldrich and dissolved at $5 \mathrm{mM}$ in DMSO. Caspase inhibitors zIETDFMK, zLEHD-FMK, and zVAD-FMK were purchased from Calbiochem (VWR International B.V., Amsterdam, The Netherlands) and dissolved at $10 \mathrm{mM}$ in DMSO. Final working concentrations of cisplatin, VPA, caspase inhibitors, and wedelolactone were diluted in standard medium.

Production of scFv:sTRAIL fusion proteins

scFv425:sTRAILwt, scFv425:sTRAILmR1-5, and MOCK-scFv:sTRAILmR1-5, targeted at the B-cell marker CD20, were constructed and produced essentially as described previously using expression vector pEE14 [10]. This plasmid encodes an N-terminal hemagglutinin (HA) tag upstream of two multiple cloning sites (MCS). In the first MCS, the high-affinity antibody fragment scFv425 (Vh-(G4S)3-Vl format) [26] was directionally inserted using the unique SfiI and NotI restriction enzyme sites. Alternatively, the upstream MCS of pEE14 was used to insert DNA fragment scFvCD20. The synthetic DNA sequence encoding scFvCD20 was generated by splice overhang extension polymerase chain reaction (PCR) technology using published sequence data of the heavy chain $(\mathrm{VH})$ and light chain (VL) domains of the murine anti-CD20 mAb 2B8. The VH and VL sequences were genetically linked via a flexible peptide linker $\left((\mathrm{GGGGS})_{3}\right)$. Moreover, restriction enzyme sites SfiI (GGCCCAGCCGG) and NotI (GCGGCCGC) were added to the 5'-end and 3'end of the sequence, yielding a 756-bp DNA fragment. In the second MCS, a PCR-truncated 593-bp DNA fragment encoding the extracellular domain of human TRAIL (sTRAIL) was cloned in frame using restriction enzymes XhoI and HindIII, yielding plasmid pEE14-scFv425:sTRAILwt. Alternatively, the cDNA encoding sTRAILmR1-5 was inserted in the second MCS. This sTRAIL mutant encodes five amino acid substitutions compared to sTRAIL-wt [25] (see Table 1). The resultant expression vectors were transfected into CHOK1 cells using Fugene 6 reagent (Roche Diagnostics, Almere, The Netherlands) according to manufacturer's instructions. Transfectants were selected by the glutamine synthetase system as described [27]. Single-cell sorting using the MoFlo high speed cell sorter (Cytomation, Fort Collins, CO, USA) established clones of scFv425:sTRAILwt, stably secreting $2.1 \mu \mathrm{g} / \mathrm{ml}$, scFv425:sTRAILmR1-5, stably secreting $2.7 \mu \mathrm{g} / \mathrm{ml}$ and MOCK-scFv:sTRAILmR1-5, stably secreting $2.3 \mu \mathrm{g} / \mathrm{ml}$.

Table 1 Changes in amino acid sequence of the sTRAIL domain of scFv425:sTRAILmR1-5 compared to scFv425:sTRAILwt

\begin{tabular}{|c|c|c|c|c|c|c|c|c|c|c|}
\hline Amino acid pos. & 189 & 191 & 193 & 199 & 201 & 213 & 215 & 264 & 266 & 267 \\
\hline scFv425:sTRAILwt & Tyr & $\operatorname{Arg}$ & Gln & Asn & Lys & Tyr & Ser & His & Ile & Asp \\
\hline scFv425:sTRAIL-mR1 & Tyr & Arg & $\mathrm{Ser}$ & Val & $\operatorname{Arg}$ & $\operatorname{Trp}$ & Asp & His & Ile & Asp \\
\hline
\end{tabular}


TRAIL receptor selective ELISA

TRAIL receptor binding selectivity of scFv425:sTRAILwt and scFv425:sTRAILmR1-5 was investigated with a catching-type Enzyme-Linked ImmunoSorbent Assay (ELISA) with either TRAIL-R1:Fc or TRAIL-R2:Fc (both from Alexis, 10P's BVBA) coated to the plates. Briefly, maxisorb ELISA plates were coated overnight with $1 \mu \mathrm{g} / \mathrm{ml}$ TRAIL-R1:Fc or TRAIL-R2:Fc, blocked with phosphatebuffered saline (PBS), $0.1 \%$ Tween, or 3\% Bovine Serum Albumine (Sigma), washed twice with PBS and 0.1\% Tween, and incubated for $3 \mathrm{~h}$ with scFv425:sTRAILwt and scFv425:sTRAILmR1-5, respectively. Specific binding was assessed by staining for the N-terminal hemagglutinin tag using Horseradish Peroxidase-conjugated anti-HA antibody (Roche). Specific binding was visualized using 3,3',5,5'Tetramethylbenzidine (Sigma) and measured using an ELISA plate reader at OD450. Where indicated, incubation with scFv425:sTRAILwt or scFv425:sTRAILmR1-5 was performed in the presence of soluble TRAIL-R1:Fc, TRAILR2:Fc, or Flag-tagged sTRAIL.

EGFR-specific binding of scFv425:sTRAIL fusion proteins

EGFR-specific binding of scFv425:sTRAILwt and scFv425:sTRAILmR1-5 was assessed by flow cytometry using the EGFR-positive tumor cell line Jurkat.EGFRvIII. In short, $1 \times 10^{6}$ cells were incubated with fusion protein (300 $\mathrm{ng} / \mathrm{ml}$ ). Specific binding was detected using PEconjugated anti-TRAIL mAb B-S23 (Diaclone SAS, Besançon, France) and subsequent fluorescent-activated cell sorting analysis using a Calibur flow cytometer (Beckman Coulter, Mijdrecht, The Netherlands). Incubations were carried out for $45 \mathrm{~min}$ at $0^{\circ} \mathrm{C}$ and were followed by two washes with serum-free medium.

EGFR-restricted induction of apoptosis by scFv425: sTRAIL fusion proteins

EGFR-restricted induction of apoptosis by the scFv425: sTRAIL fusion proteins was assessed by loss of mitochondrial membrane potential $(\Delta \Psi)$ or by crystal violet cytotoxicity assay as described in more detail below. Where indicated, treatment with scFv425:sTRAIL fusion proteins or the MOCK-scFv:sTRAILmR1-5 was performed in the presence or absence of $\mathrm{mAb} 425(3 \mu \mathrm{g} / \mathrm{ml})$ or $\mathrm{mAb} 2 \mathrm{E} 5$ $(1 \mu \mathrm{g} / \mathrm{ml})$. Loss of mitochondrial membrane potential $(\Delta \Psi): \Delta \Psi$ was analyzed using the stain DiOC6 (Eugene, The Netherlands) as previously described [10]. Briefly, cells were precultured in a 48 -well plate at a concentration of $0.3 \times 10^{5}$ cells/well. Subsequently, cells were treated for $16 \mathrm{~h}$ with the various experimental conditions, after which cells were harvested and incubated for 20 min with DiOC6
$(0,1 \mu \mathrm{M})$ at $37^{\circ} \mathrm{C}$, harvested $(1,000 \mathrm{~g}, 5 \mathrm{~min})$, resuspended in PBS, and assessed for staining by flow cytometry. Cell viability assessed by crystal violet cytotoxicity assay: cells were precultured in a 96-well plate at a concentration of $0.3 \times$ $10^{5}$ cells/well. Subsequently, cells were treated for $16 \mathrm{~h}$ with the various experimental conditions in a final volume of $200 \mu \mathrm{l}$. Cell viability was determined by crystal violet staining (Sigma, Germany) as described previously [8]. Experimental apoptosis induction was quantified as the percentage of apoptosis induction compared to medium control. Each experimental condition consisted of six independent wells. Luminescent assay for caspase-8, caspase-9, and caspase-3 or caspase-7 activity: caspase activity was assessed using Caspase-Glo ${ }^{\circledR} 8$ Assay, Caspase-Glo ${ }^{\circledR} 9$ Assay, and CaspaseGlo $^{\circledR} 3$ or 7 Assay according to manufacturer's instructions (Promega Benelux BV, Leiden, The Netherlands). The assays are based on the cleavage of nonluminescent substrates by activated caspases into a luminescent product. Luminescence is quantified using an ELISA plate reader.

Immunoblot analysis of caspase-8, cFLIP $P_{L}$ and $N F \kappa B$

Cells were seeded in 6-well plates at a final concentration of $2.0 \times 10^{6}$ cells $/ \mathrm{ml}$ and treated as indicated. Cell lysates were prepared and immunoblot analysis was performed essentially as described before [26]. Antibodies used were anti-caspase-8 (Cell signaling technology, Beverly, MA, USA), anti-cFLIP ${ }_{\mathrm{L}}$ clone NF6 (Alexis), NFKB p100/p52, NFkB p105/p50, NFkB p65 (all from Santa-Cruz; TebuBio, Heerhugowaard, The Netherlands). Appropriate secondary peroxidase-conjugated antibodies were from DAKO Cytomation (Glostrup, Denmark).

\section{Selective knockdown of TRAIL-R1 or TRAIL-R2} using small inhibitory (si)RNA

OVCAR-3 cells were precultured in 6-well plates to $60 \%$ confluency, after which, cells were treated with $10 \mathrm{pM}$ TRAIL-R1 siRNA (sense: 5'-CACCAAUGCUUCCAA CAAU-3'; antisense: 5'-AUUGUUGGAAGCAUUGGU-3') or TRAIL-R2 siRNA (sense:5'-GACCCUUGUGCUCGUU GUC-3'; antisense: 5'-GACAACGAGCACAAGGGUC-3'; Eurogentec S.A., Liege, Belgium). Treated cells were cultured for 3 days, after which, selective TRAIL receptor downregulation was verified by flow cytometry. Subsequently, cells were plated in a 48 -well plate at $3 \times 10^{4}$ cells/well and treated with scFv425:sTRAILwt, scFv425:sTRAILmR1-5, agonistic TRAIL-R1 mAb, or agonistic TRAIL-R2 mAb. Apoptosis was assessed by $\Delta \psi$. For siRNA apoptosis experiments, the experimental apoptosis was calculated using the following formula: experimental apoptosis = (specific apoptosis - spontaneous apoptosis)/(100 - spontaneous apoptosis) $\times 100 \%$. 
Synergistic induction of apoptosis by scFv425:sTRAIL fusion proteins and conventional and experimental therapeutic drugs

Cells were plated at $3.0 \times 10^{4}$ cells/well in a 48 -well plate and allowed to adhere overnight. Subsequently, cells were concurrently treated for $24 \mathrm{~h}$ with scFv425:sTRAILwt or scFv425:sTRAILmR1-5 with or without cisplatin or histone deacetylase inhibitor VPA. Additive or synergistic apoptotic effects were determined using the cooperativity index (CI). CI was determined with the following formula: the sum of apoptosis induced by single-agent treatment divided by apoptosis induced by combination treatment. When $\mathrm{CI}<0.9$, treatment was termed synergistic; when $0.9<\mathrm{CI}<1.1$, treatment was termed additive; when $\mathrm{CI}>$ 1.1 , treatment was termed antagonistic.

\section{IL-8 ELISA}

To determine IL-8 production in response to scFv425:sTRAILwt and scFv425:sTRAILmR1-5, RC21, PC3-M, HT-29, A549, and WiDr cells were treated with $850 \mathrm{ng} / \mathrm{ml}$ fusion protein in the presence or absence of total caspase inhibitor zVAD-FMK. After $16 \mathrm{~h}$, supernatants were analyzed for IL-8 levels using IL-8 ELISA according to manufacturer's protocol (Sanquin reagents, Amsterdam, The Netherlands).

\section{Statistical analysis}

Data reported are mean values + standard error of the mean of at least three independent experiments. Where appropriate, statistical analysis was performed using two-sided, unpaired Student' s $t$-test. For all statistical analyses, a statistically significant difference was defined as $p<0.05$.

\section{Results}

EGFR-selective binding and induction of apoptosis by scFv425:sTRAILwt and scFv425:sTRAILmR1-5

To determine whether the sTRAILmR1-5 domain of scFv425:sTRAILmR1-5 had any influence on EGFRspecific binding compared to scFv425:sTRAILwt, Jurkat. EGFRvIII cells were incubated with scFv425:sTRAILwt and scFv425:sTRAIL-mR1 and assessed for EGFR-specific binding (Fig. 1a). As expected, both fusion proteins possessed identical binding characteristics to Jurkat.EGFRvIII (Fig. 1a). Binding was EGFR-specific because pre-incubation with parental EGFR-blocking mAb 425 specifically inhibited the binding of both scFv425:sTRAILwt and scFv425:sTRAILmR1-5 (data not shown).
To determine whether scFv425:sTRAILmR1-5, similar to scFv425:sTRAILwt, showed EGFR-restricted apoptotic activity, EGFR-positive RC21 cells were treated with $350 \mathrm{ng} / \mathrm{ml} \mathrm{scFv} 425$ :sTRAILwt and scFv425:sTRAILmR1-5. Both fusion proteins potently induced apoptosis in RC21 cells (Fig. 1b). Importantly, induction of apoptosis by scFv425:sTRAILwt and scFv425:sTRAILmR1-5 in RC21 cells was specifically inhibited by co-incubation with molar excess of parental EGFR-blocking mAb 425 (Fig. 1b). Thus, scFv425:sTRAILmR1-5 selectively binds to EGFR, after which, apoptosis is induced by TRAIL receptor crosslinking.

Subsequently, we determined whether the EGFR-selective accretion of STRAILmR1-5 to the cell surface of tumor cells resulted in enhanced apoptotic activity compared to nontargeted sTRAILmR1-5. To this end, EGFR-positive cells were treated with scFv425:sTRAILmR1-5 and a MOCKscFv:sTRAILmR1-5 fusion protein containing an scFv antibody fragment of irrelevant specificity targeted at the B-cell marker CD20. Dose escalation experiments, exemplified here for PC-3M (Fig. 1c), identified that scFv425:sTRAILmR1-5 showed superior apoptotic activity compared to MOCK-scFv: sTRAILmR1-5 in PC-3M, A431, and RC21 cells (Fig. 1d). Thus, EGFR-selective binding results in superior apoptotic activity of scFv425:sTRAILmR1-5 compared to the nontargeted soluble MOCK-scFv:sTRAILmR1-5.

scFv425:sTRAILmR1-5 has superior apoptotic activity on a subset of EGFR-positive solid tumor cell lines

To evaluate the apoptotic activity of scFv425:sTRAILmR1-5, we tested a panel of ten EGFR-positive tumor cell lines with scFv425:sTRAILmR1-5 and scFv425:sTRAILwt. Dose escalation experiments, exemplified here with PC-3M cells (Fig. 2a), identified that scFv425:sTRAILmR1-5 had superior apoptotic activity compared to scFv425:sTRAILwt in OVCAR-3, A549, HT-29, HS-683, A431, and PC-3M cells (Fig. 2a and b and Supplementary Fig. 1). Dose escalation experiments, exemplified here for RC21 (Fig. 2c), on RC21, WiDr, Sk-rc-52, and A172 identified no significant difference in apoptotic activity (Fig. 2d and Supplementary Fig. 2). Of note, in the latter cell lines, scFv425:sTRAILmR1-5 consistently showed a nonsignificant trend toward higher apoptotic activity compared to scFv425:sTRAILwt.

To determine whether scFv425:sTRAILmR1-5 retained its superior apoptotic activity compared to scFv425:sTRAILwt upon cotreatment with other conventional or experimental anticancer therapeutics, OVCAR-3 cells were treated with the respective fusion proteins alone or in combination with VPA or cisplatin (Fig. 2e and f). Importantly, cotreatment with cisplatin and VPA synergistically enhanced the apoptotic activity of both scFv425:sTRAILwt (CI of 0.73 and 0.42 , 
Fig. 1 EGFR-selective binding and induction of apoptosis by scFv425:sTRAILwt and scFv425:sTRAILmR1-5. a Jurkat.EGFRvIII cells were incubated with PE-conjugated anti-TRAIL mAb B-S23 (solid fill), scFv425:sTRAILwt + mAb B-S23 (solid line), or scFv425:sTRAILmR1-5 + mAb $\mathrm{B}-\mathrm{S} 23$ (dotted line), after which specific binding was assessed by flow cytometry. b EGFRpositive RC21 cells were treated with $350 \mathrm{ng} / \mathrm{ml}$ scFv425:sTRAILwt or scFv425:sTRAILmR1-5 in the absence or presence of parental EGFR-blocking $\mathrm{mAb}$ 425. c PC-3M cells were treated for $16 \mathrm{~h}$ with increasing concentrations of scFv425:sTRAILmR1-5 or the nontargeted MOCK-scFv:sTRAILmR1-5. d EGFR-positive cell lines $\mathrm{PC}-3 \mathrm{M}, \mathrm{A} 431$, and RC21 were treated with $850 \mathrm{ng} / \mathrm{ml}$ scFv425:sTRAILmR1-5 or MOCK-scFv:sTRAILmR1-5. Apoptosis was assessed by $\Delta \Psi$. ${ }^{* *} p<0.001,{ }^{* * *} p<0.0001$
A

B

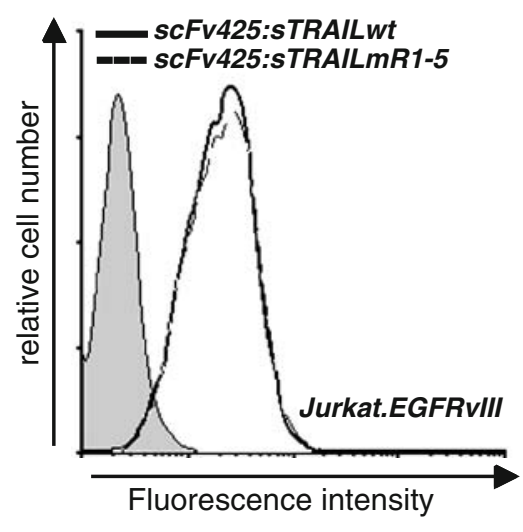

C

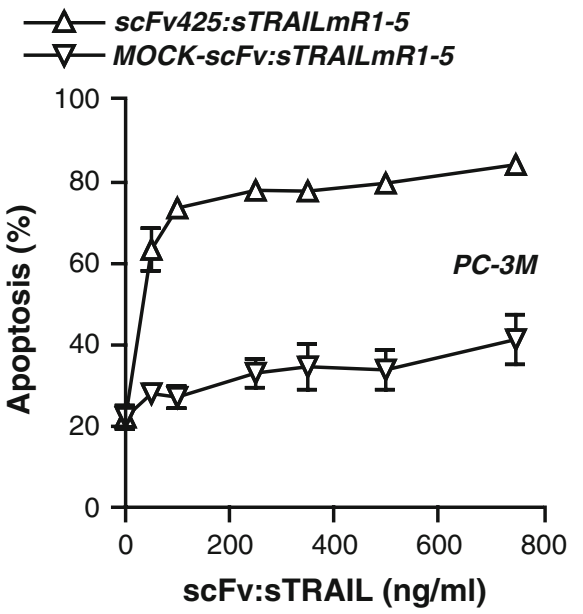

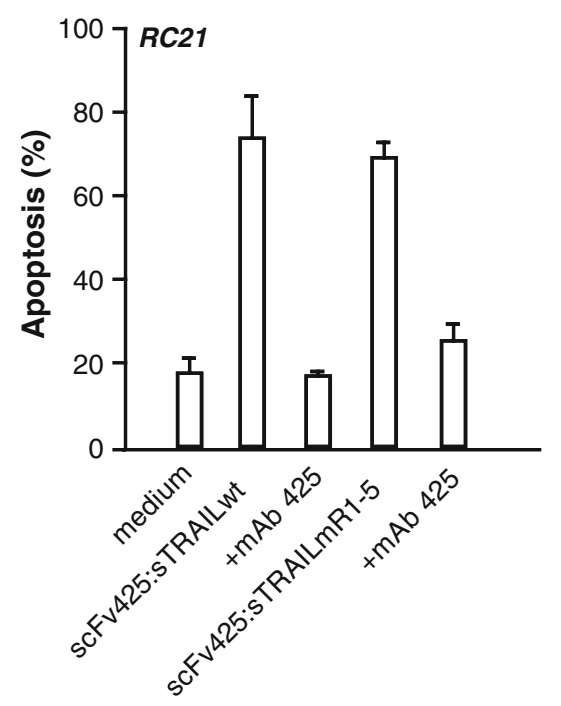

D
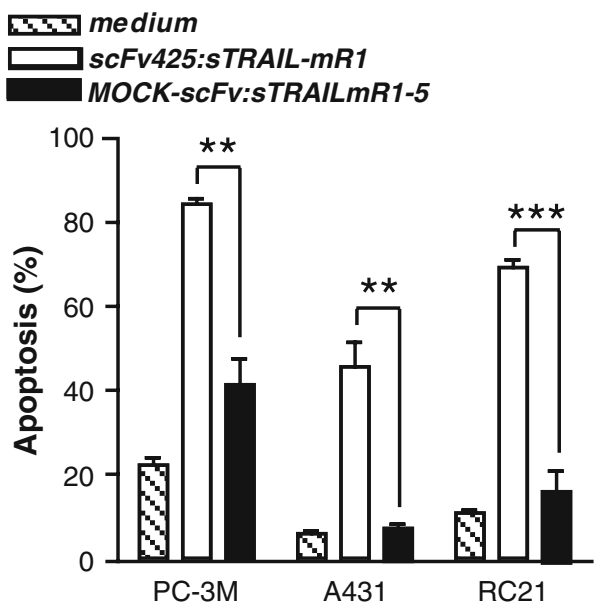

respectively) and scFv425:sTRAILmR1-5 (CI of 0.57 and 0.42, respectively). However, the scFv425:sTRAILmR1-5 fusion protein retained a significantly higher pro-apoptotic activity compared to scFv425:sTRAILwt $(p<0.001$ and $p<$ 0.05 , respectively). The synergistic effect of cotreatment with VPA and cisplatin was still fully dependent on EGFRselective binding of the respective fusion protein because cotreatment with EGFR-blocking mAb 425 abrogated the induction of apoptosis (data not shown).

The apoptotic activity of scF425:sTRAILwt and scFv425:sTRAILmR1-5 does not correlate with EGFR- or TRAIL receptor expression

Because the sTRAILmR1-5 domain was described to be selective for TRAIL-R1, we subsequently analyzed whether the differences in apoptotic activity of scFv425:sTRAILwt and scFv425:sTRAILmR1-5 in the subset of cell lines was due to differential TRAIL receptor expression. To this end, we determined the relative TRAIL receptor expression levels of the cell lines as well as the expression level of EGFR (Table 2). In agreement with our previous findings for scFv425:sTRAILwt, the activity of scFv425:sTRAILmR1-5 did not correlate with the level of EGFR expression. Importantly, there was also no correlation between the expression levels of TRAIL-R1, TRAIL-R2, or TRAIL-R4 and the apoptotic activity of the fusion proteins. In addition, there was not a clear correlation between the various ratios of TRAIL-R2/TRAIL-R1, TRAIL-R1/ TRAIL-R4, or TRAIL-R2/TRAIL-R4, although four out of the six $(66 \%)$ cell lines that were significantly more sensitive to scFv425:sTRAILmR1-5 appeared to have a more balanced TRAIL-R2/TRAIL-R1 ratio, in comparison to two out of four $(50 \%)$ of the other cell lines. A particularly intriguing finding is the fact that some of the cell lines, most sensitive to scFv425:sTRAILmR1-5, 
Fig. 2 Fusion protein scFv425:sTRAILmR1-5 has superior apoptotic activity on a subset of EGFR-positive solid tumor cell lines. a Doseresponse curve of induction of apoptosis in PC-3M cells by increasing concentrations of scFv425:sTRAILwt or scFv425:sTRAILmR1-5. b OVCAR-3, A549, HT-29, HS-683, A431, and PC-3M cells were treated with scFv425:sTRAILwt (850 ng/ml) or scFv425:sTRAILmR1-5 $(850 \mathrm{ng} / \mathrm{ml})$. Cell viability in HS-683 was assessed by crystal violet toxicity assay. c Doseresponse curve of apoptosis induction in RC21 cells treated with increasing concentrations of scFv425:sTRAILwt or scFv425:sTRAILmR1-5. d RC21, WiDr, Sk-rc-52, and A172 cells were treated with scFv425:sTRAILwt $(850 \mathrm{ng} / \mathrm{ml})$ or scFv425:sTRAILmR1-5 ( $850 \mathrm{ng} / \mathrm{ml})$. e OVCAR-3 cells were treated alone or with a combination of the HDACi VPA $(2 \mathrm{mM})$ and scFv425:sTRAILwt $(350 \mathrm{ng} / \mathrm{ml})$ or scFv425:sTRAILmR1-5 (350 ng/ml). f OVCAR-3 cells were treated alone or with a combination of cisplatin $(3 \mu \mathrm{g} / \mathrm{ml})$ and $\mathrm{scFv} 425$ : sTRAILwt $(350 \mathrm{ng} / \mathrm{ml})$ or scFv425:sTRAILmR1-5 (350 ng/ml). Unless indicated otherwise, apoptosis was assessed by $\Delta \Psi .{ }^{*} p<0.05$, ${ }^{* *} p<0.001, * * * p<0.0001$
A

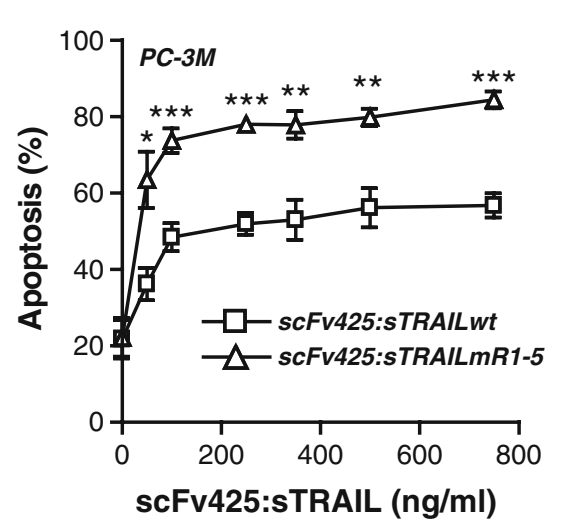

C

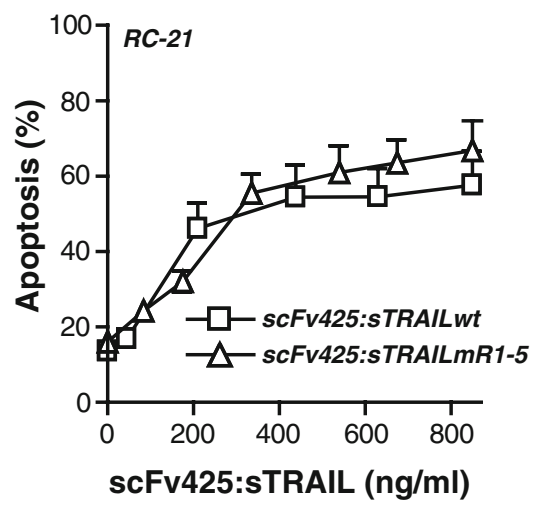

E

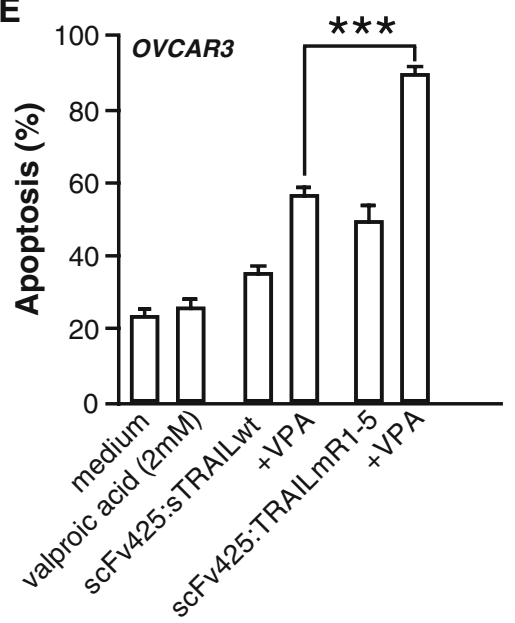

B

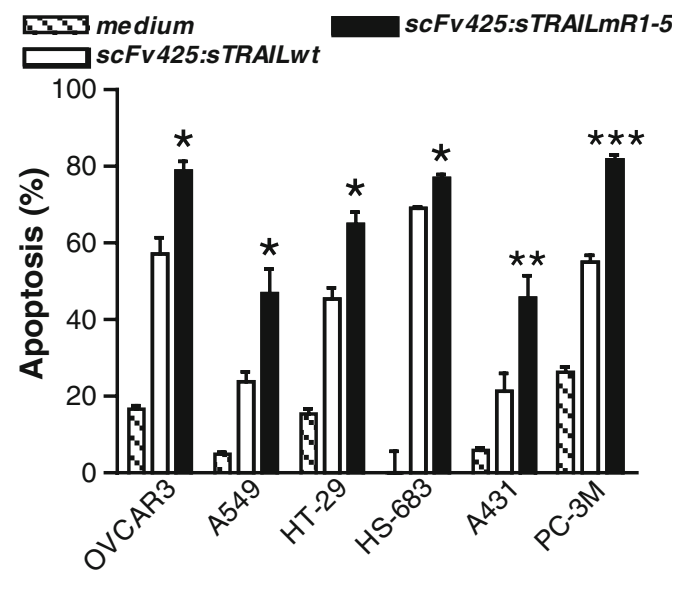

D

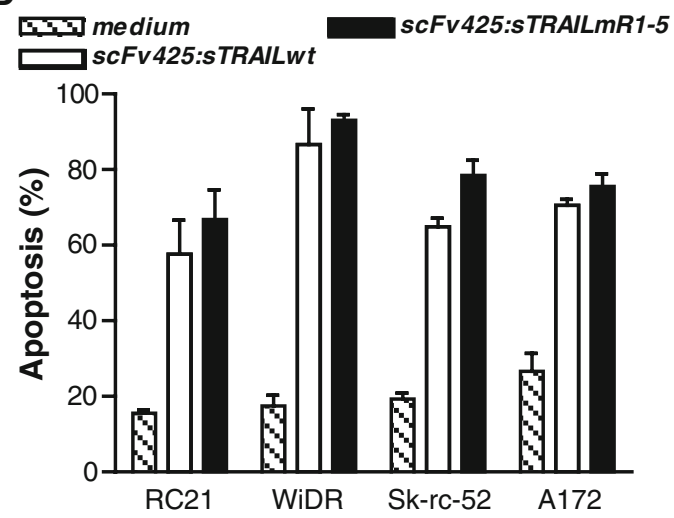

F

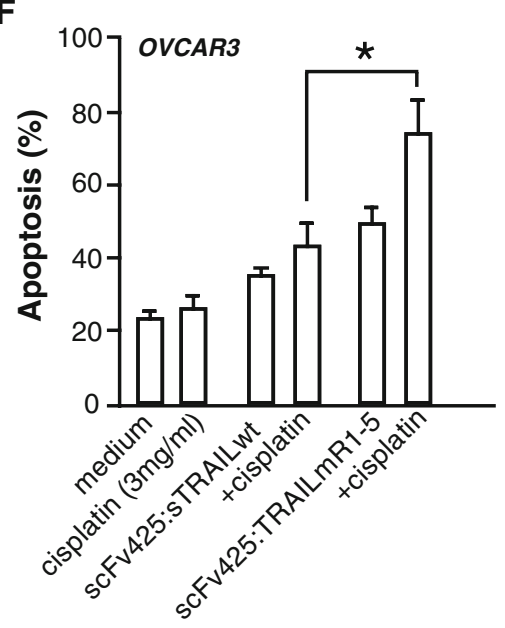

have a very low expression of TRAIL-R1 (Table 2, HT29; MFI of 8.1, HS683; MFI of 0.5, PC-3M; MFI of 1.9).

scFv425:sTRAILwt but also scFv425:sTRAILmR1-5 binds to both TRAIL-R1 and TRAIL-R2

The sTRAILmR1-5 mutant we genetically fused to scFv425 was reported by MacFarlane et al. to selectively activate TRAIL-
R1. However, we found no clear correlation between the TRAIL-R1 status and activity of scFv425:TRAILmR1-5; within certain cell lines, very low TRAIL-R1 expression coincided with high apoptotic activity of scFv425:sTRAILmR1-5. Therefore, we performed a catching-type ELISA, in which plates were coated either with TRAIL-R1:Fc or TRAIL-R2:Fc, to assess whether the sTRAILmR1-5 domain was indeed selective for TRAIL-R1. As expected, binding of scFv425:sTRAILwt was 
Table 2 EGFR/TRAIL receptor expression and the correlation with the apoptotic activity of scFv425:sTRAILwt/scFv425:sTRAILmR1-5

\begin{tabular}{|c|c|c|c|c|c|c|c|c|c|c|}
\hline Cell line & $\begin{array}{l}\text { scFv425: } \\
\text { sTrailwt }\end{array}$ & $\begin{array}{l}\text { scFv425: } \\
\text { sTrailmR1-5 }\end{array}$ & $P$-value & EGFR & $\begin{array}{l}\text { TRAIL- } \\
\text { R1 }\end{array}$ & $\begin{array}{l}\text { TRAIL- } \\
\text { R2 }\end{array}$ & $\begin{array}{l}\text { TR2/ } \\
\text { TR1 }\end{array}$ & $\begin{array}{l}\text { TRAIL- } \\
\text { R4 }\end{array}$ & $\begin{array}{l}\text { TR1/ } \\
\text { TR4 }\end{array}$ & $\begin{array}{l}\text { TR2/ } \\
\text { TR4 }\end{array}$ \\
\hline OVCAR-3 & $57,1 \pm 8,6$ & $78,8 \pm 5,0$ & 0.0048 & 629 & 167,1 & 207,8 & 1,2 & n.a. & - & - \\
\hline A549 & $23,8 \pm 5,7$ & $46,8 \pm 14,4$ & 0.0106 & 1.755 & 69,7 & 151,5 & 2,2 & 8,3 & 8,4 & 18,2 \\
\hline HT-29 & $51,5 \pm 1,7$ & $65,2 \pm 4,5$ & 0.0468 & 317 & 8,1 & 35,1 & 4,3 & 5,2 & 1,6 & 6,8 \\
\hline HS683 & $69 \pm 0,9$ & $76,87 \pm 2,1$ & 0.0313 & 436 & 0,5 & 44,8 & 98,4 & 8,6 & 0,1 & 5,2 \\
\hline A431 & $21,3 \pm 8,1$ & $45,6 \pm 10,1$ & 0.0313 & 2727 & 4,7 & 7,8 & 1,7 & n.a. & - & - \\
\hline PC3-M & $56,8 \pm 3,2$ & $84,4 \pm 2,2$ & 0.0003 & 34 & 1,9 & 45,3 & 23,4 & 6,86 & 0,3 & 6,6 \\
\hline $\mathrm{RC} 21$ & $57,6 \pm 18,0$ & $66,8 \pm 13,6$ & n.s. & 3.648 & 214,9 & 398,6 & 1,9 & 29,6 & 7,3 & 13,5 \\
\hline Sk-rc52 & $64,9 \pm 4,6$ & $78,49 \pm 6,9$ & n.s. & 1.263 & 12,1 & 133,0 & 11,0 & 13,5 & 0,9 & 9,9 \\
\hline A172 & $70,5 \pm 2,3$ & $75,5 \pm 4,8$ & n.s. & 182 & 0,6 & 112,2 & 178,2 & 3,6 & 0,2 & 31,2 \\
\hline WiDR & $86,6 \pm 13,3$ & $93 \pm 2,2$ & n.s. & 256 & 17,8 & 56,3 & 3,2 & 1,9 & 9,5 & 29,9 \\
\hline
\end{tabular}

The percentage of induction of apoptosis by scFv425:sTRAILwt and scFv425:sTRAILmR1-5 are the percentages obtained by treatment with $850 \mathrm{ng} / \mathrm{ml}$. $P$-values were obtained using unpaired Student's $t$-test. The MFI values of EGFR and TRAIL receptor expression are representatives of three independent experiments

n.s. No significant difference, n.d. not determined

observed in both TRAIL-R1:Fc and TRAIL-R2:Fc coated plates (Fig. 3a and b, open squares). Surprisingly, however, scFv425:sTRAILmR1-5 also proved to bind to both TRAILR1:Fc and TRAIL-R2:Fc (Fig. 3a and b, open triangles).

To establish whether this interaction was indeed specific, we competitively inhibited the binding of scFv425:sTRAILwt and scFv425:sTRAILmR1-5, as observed in the TRAIL-R1: Fc ELISA, using soluble TRAIL-R1:Fc and TRAIL-R2:Fc (Fig. 3c and d). Importantly, binding of both fusion proteins was competitively inhibited by TRAIL-R1:Fc and TRAILR2:Fc (Fig. 3c and d). Of note, whereas scFv425:sTRAILwt binding was more efficiently inhibited by addition of TRAIL-R2:Fc, binding of scFv425:sTRAIL-mR1-5 was more efficiently inhibited by TRAIL-R $1: F c$. Thus, scFv425:sTRAILmR1-5 appears to preferentially bind to TRAIL-R1, whereas scFv425:sTRAILwt appears to preferentially bind to TRAIL-R2. In addition, binding of scFv425:sTRAILwt and scFv425:sTRAIL-mR1-5 to TRAIL-R1:Fc was competitively inhibited by Flag-tagged wild-type sTRAIL (Fig. 3e). Together, these results clearly show that scFv425:sTRAILmR1-5 specifically binds to not only TRAIL-R1 but also TRAIL-R2.

scFv425:sTRAILwt but also scFv425:sTRAILmR1-5 activate apoptosis via both TRAIL-R1 and TRAIL-R2

To determine whether binding of scFv425:sTRAILmR1-5 to TRAIL-R2 also had functional consequences, RC21 renal cancer cells (TRAIL-R $1^{+} / \mathrm{R} 2^{+}$) were treated with scFv425:sTRAILmR1-5 in the presence of TRAIL-R1 blocking $\mathrm{mAb}$, TRAIL-R2 blocking $\mathrm{mAb}$, or a combination of both mAbs. Importantly, induction of apoptosis by scFv425:sTRAILmR1-5 in RC21 cells was significantly inhibited not only by TRAIL-R $1 \mathrm{mAb}$ but also by the
TRAIL-R2 mAb (Fig. 4a). Of note, the TRAIL-R2 mAb was even more effective than the TRAIL-R1 $\mathrm{mAb}$ in blocking scFv425:sTRAILmR1-5 activity. Cotreatment with both blocking mAbs abrogated the apoptotic activity of scFv425:sTRAILmR1-5. Similar results were obtained for scFv425:sTRAILwt (Fig. 4b) as well as kTRAIL (Fig. 4c), an artificially cross linked sTRAIL preparation. However, compared to the scFv425:sTRAILmR1-5 fusion protein, both scFv425:sTRAILwt as well as kTRAIL were far less efficiently blocked by TRAIL-R1 mAb, TRAIL-R2 $\mathrm{mAb}$, or the combination of both mAbs.

In addition, treatment of RC21 cells with scFv425: sTRAILmR1-5 in the presence of TRAIL-R1:Fc or TRAILR2:Fc potently inhibited the induction of apoptosis (Fig. 4d). Of note, TRAIL-R2:Fc was more efficient than TRAIL-R1: $\mathrm{Fc}$ in blocking apoptosis. Similarly, TRAIL-R1:Fc and TRAIL-R2:Fc also inhibited the apoptotic activity of scFv425:sTRAILwt and kTRAIL (Fig. 4d) although, again, to a lesser extent than scFv425:sTRAILmR1-5.

To further verify that both TRAIL-R1 and TRAIL-R2 signaling are involved in activation of apoptosis in solid tumor cells by scFv425:sTRAILwt and scFv425:sTRAILmR1-5, siRNA-mediated knockdown of TRAIL-R1 or TRAIL-R2 was performed in OVCAR-3 cells. Normally, OVCAR-3 cells express TRAIL-R1 and TRAIL-R2 at approximately equal levels on the cell surface (Fig. 5a). In addition, treatment with scFv425:sTRAILwt and scFv425:sTRAILmR1-5 potently activates apoptosis (Fig. 5b). Treatment of OVCAR-3 cells with TRAIL-R1 specific siRNA resulted in $\sim 92 \%$ downregulation of TRAIL-R1 (Fig. 5c). Similarly, treatment with TRAIL-R2 specific siRNA resulted in $\sim 91 \%$ downregulation of TRAIL-R2 (Fig. 5d).

The absence of TRAIL-R1 or TRAIL-R2 signaling upon siRNA treatment was confirmed using TRAIL receptor 
Fig. 3 scFv425:sTRAILwt and scFv425:sTRAILmR1-5 bind to and activate apoptosis via TRAIL-R1 and TRAIL-R2. TRAIL receptor-specific binding of scFv425:sTRAILwt and scFv425:sTRAILmR1-5 was assessed using a catching-type ELISA with TRAIL-R1:Fc or TRAIL-R2:Fc coated to the bottom. a Increasing concentrations of scFv425:sTRAILwt and scFv425:sTRAILmR1-5 were incubated with TRAIL-R1:Fc coated plates. b Increasing concentrations of scFv425:sTRAILwt and scFv425:sTRAILmR1-5 were incubated with TRAIL-R2:Fc coated plates. c Binding of scFv425:sTRAILwt $(850 \mathrm{ng} / \mathrm{ml})$ was competitively inhibited by co-incubation with increasing concentrations of TRAIL-R1:Fc and TRAIL-R2:Fc. d Binding of scFv425:sTRAILmR1-5 (850 ng/ml) was competitively inhibited by co-incubation with increasing concentrations of TRAIL-R1:Fc and TRAIL-R2: Fc. e Binding of scFv425:sTRAILwt and scFv425:sTRAILmR1-5 $(600 \mathrm{ng} / \mathrm{ml})$ was competitively inhibited by co-incubation with increasing concentrations of recombinant Flag-tagged sTRAILwt. In all experiments, TRAIL receptor-specific binding was determined by spectrophotometry at OD450 as described in "Materials and methods"
A

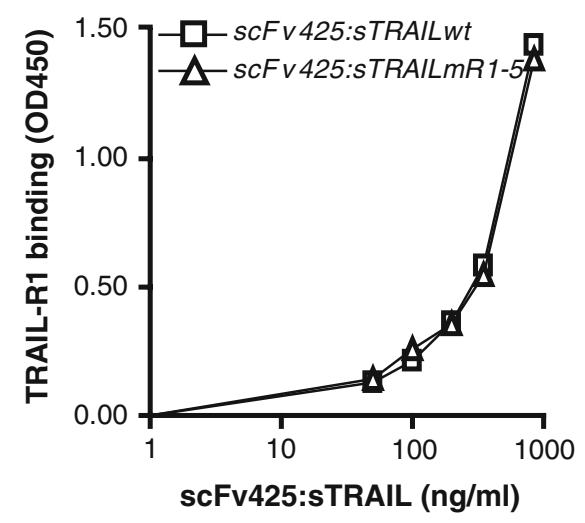

C

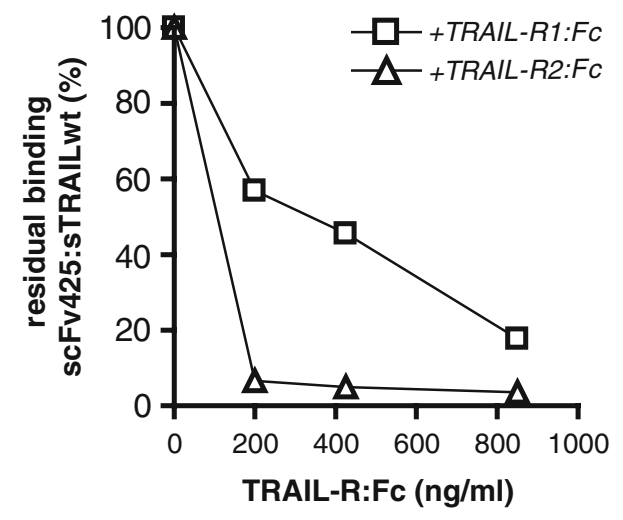

E

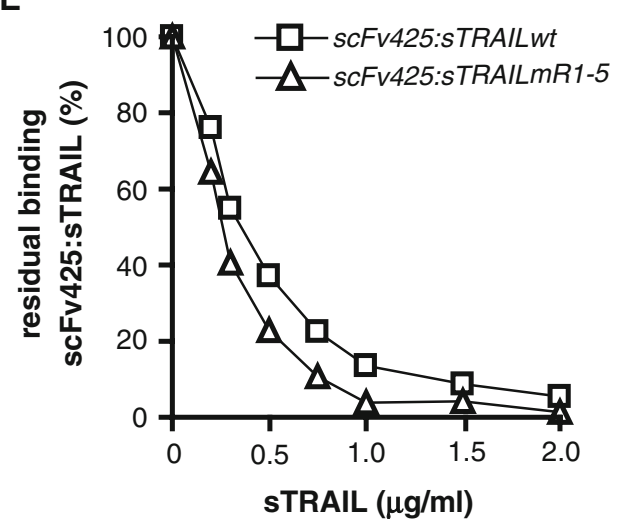

B

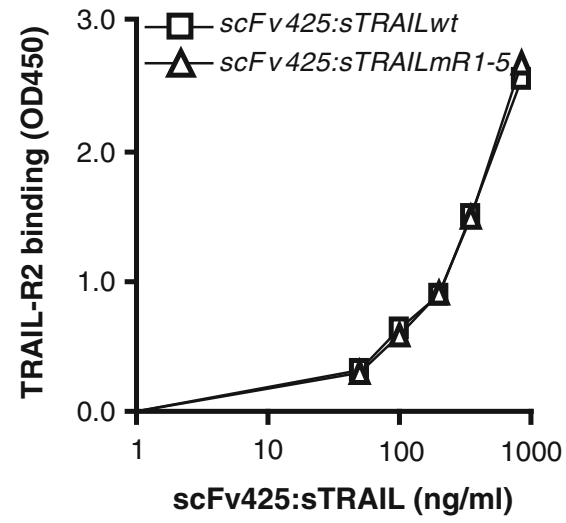

D

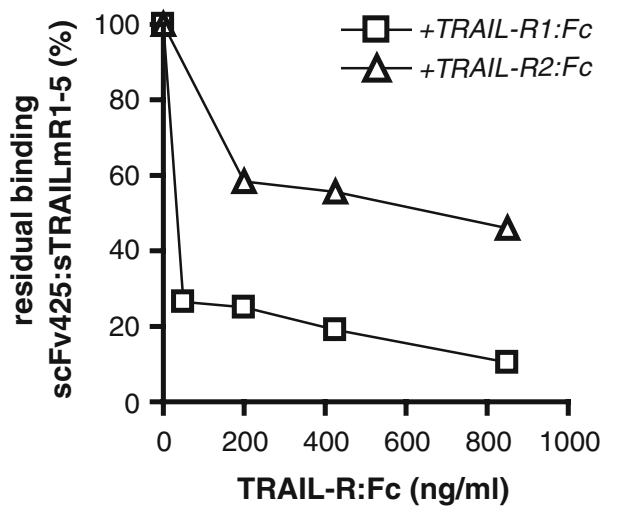

selective agonistic antibodies. A TRAIL-R1 agonistic $\mathrm{mAb}$ was largely inactive on OVCAR-3 cells treated with TRAIL-R1 siRNA (Fig. 5e), while a TRAIL-R2 agonistic mAb was largely inactive on OVCAR-3 cells treated with TRAIL-R2 siRNA (Fig. 5f). Thus, treatment with the respective TRAIL-R1 or TRAIL-R2 siRNA indeed functionally downregulates the receptor. However, scFv425:sTRAILmR1-5 potently induced apoptosis in these cells irrespective of TRAIL-R1 or TRAIL-R2 downregulation (Fig. 5e and $\mathrm{f}$ ), indicating that both receptors can be activated by scFv425:sTRAILmR1-5. In addition, the pro-apoptotic activity of scFv425:sTRAILwt was markedly reduced compared to scFv425:sTRAILmR1-5 when TRAIL-R2 was knocked down, thus, confirming previous reports that wild-type sTRAIL preferentially signals via TRAIL-R2.

scFv425:sTRAILwt and scFv425:sTRAILmR1-5 activate similar caspase signaling

The differential reliance on TRAIL-R1 or TRAIL-R2 for induction of apoptosis by scFv425:sTRAILwt and scFv425:sTRAILmR1-5 after siRNA-mediated receptor downregulation prompted us to assess whether the type 
Fig. 4 Induction of apoptosis by scFv425:sTRAILmR1-5 and MOCK-scFv:sTRAILmR1-5 is inhibited by TRAIL-R2 blocking $\mathrm{mAb}$. RC21 cells

were treated with a scFv425:sTRAILmR1-5 (500 ng/ml), b scFv425: sTRAILwt (500 ng/ml) and c kTRAIL $(50 \mathrm{ng} / \mathrm{ml})$ in the presence or absence of TRAILR1-blocking mAb $(1 \mu \mathrm{g} / \mathrm{ml})$, TRAIL-R2-blocking mAb $(1 \mu \mathrm{g} /$ $\mathrm{ml}$ ), or a combination of TRAILR1- and TRAIL-R2-blocking mAbs. d RC21 cells were treated with scFv425:sTRAILmR1-5 (500 ng/ml), scFv425:sTRAILwt (500 ng/ml), or kTRAIL (50 ng/ $\mathrm{ml})$ in the presence or absence of TRAIL-R1:Fc or TRAIL-R2:Fc (both $1 \mu \mathrm{g} / \mathrm{ml}$ ). In all experiments, apoptosis was assessed by $\Delta \Psi$
A

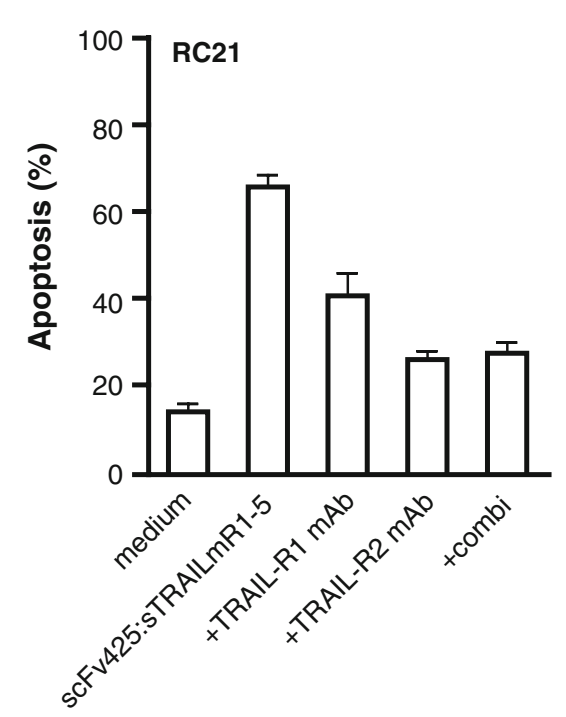

C

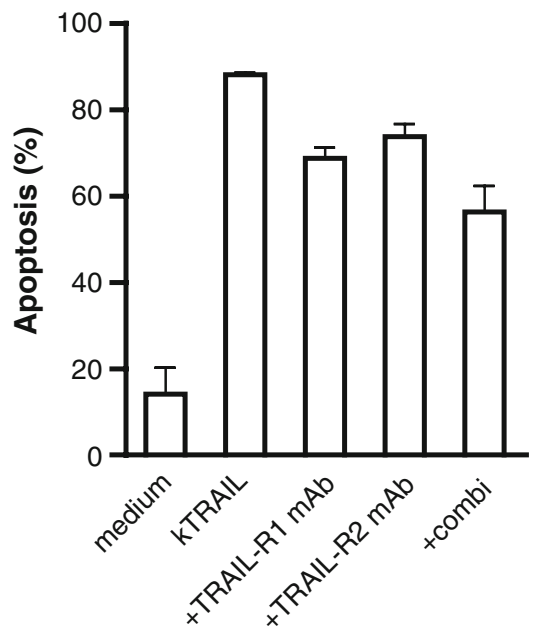

B

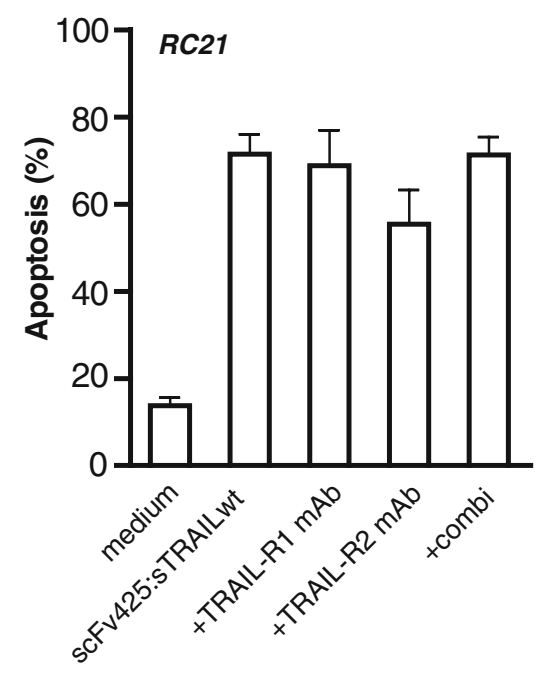

\section{D}
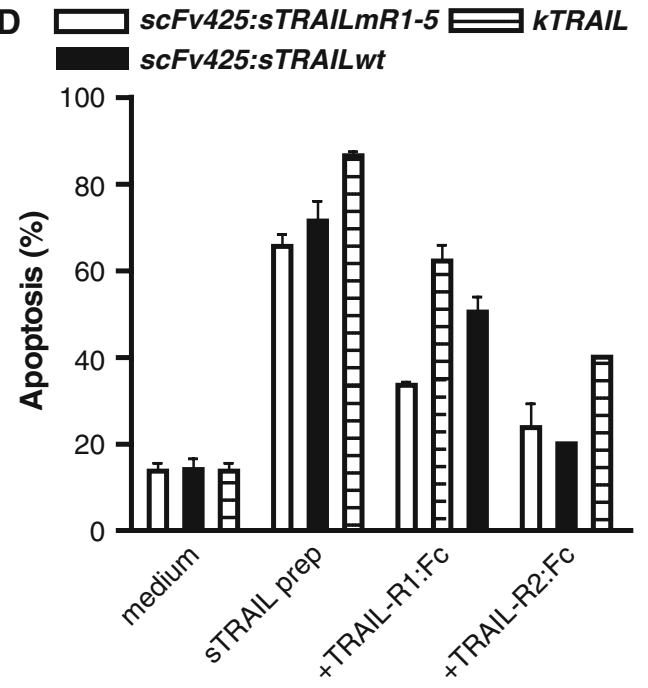

of apoptosis induced by the two fusion proteins was similar or divergent. Therefore, we treated RC21 and PC-3M cells with scFv425:sTRAILwt and scFv425:sTRAILmR1-5 and determined caspase activity at various time points. In both RC21 and PC-3M cells, induction of apoptosis by scFv425: sTRAILwt and scFv425:sTRAILmR1-5 was associated with a similar activation profile for caspase-8 (Fig. 6a), caspase-9 (Fig. 6b), and caspase-3 or caspase-7 (Fig. 6c). As expected, caspase levels for scFv425:sTRAILmR1-5 were consistently higher in PC-3M cells (Fig. 6a, b, and c). Subsequent inhibition of caspase- 8 , caspase- 9 , or total caspases confirmed that scFv425:sTRAILwt and scFv425:sTRAILmR1-5 have a similar dependency on caspases for execution of apoptosis (Fig. 6d). Interestingly, immunoblot analysis of the caspase-8 inhibitor $\mathrm{cFLIP}_{\mathrm{L}}$ revealed a striking difference between scFv425:sTRAILwt and scFv425:sTRAILmR1-5. Cells treated with scFv425: sTRAILmR1-5 displayed a total absence of cFLIP ${ }_{\mathrm{L}}$, whereas in scFv425:sTRAILwt treated cells, cFLIP $_{\mathrm{L}}$ was markedly upregulated compared to medium control (Fig. 6e and f). However, this difference was found for both $\mathrm{RC} 21$ and PC-3M cells, suggesting that it is not the underlying reason for the differential activity of scFv425:sTRAILwt and scFv425:sTRAILmR1-5.

The differential activity of scFv425:sTRAILwt and scFv425:sTRAILmR1-5 is not due to NFkB signaling

Analysis of the pro-apoptotic signaling pathways by scFv425:sTRAILwt and scFv425:sTRAILmR1-5 revealed an intriguing difference in $\mathrm{cFLIP}_{\mathrm{L}}$. Because this apoptotic modulator has been linked to the NF $\kappa B$ pathway, we further 
A

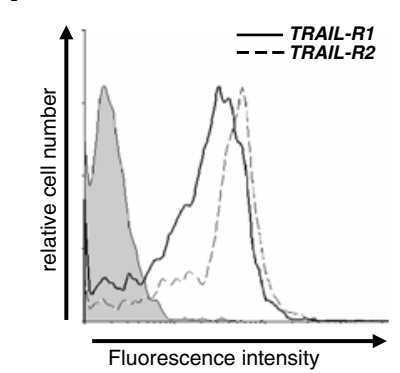

B

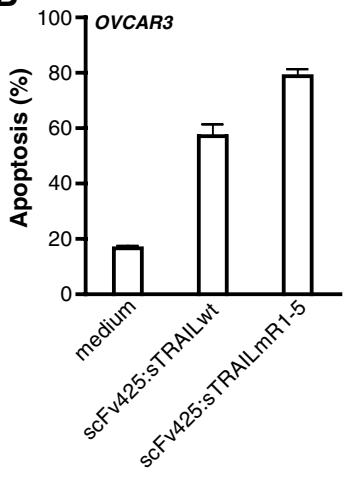

C siRna tRaIL-R1

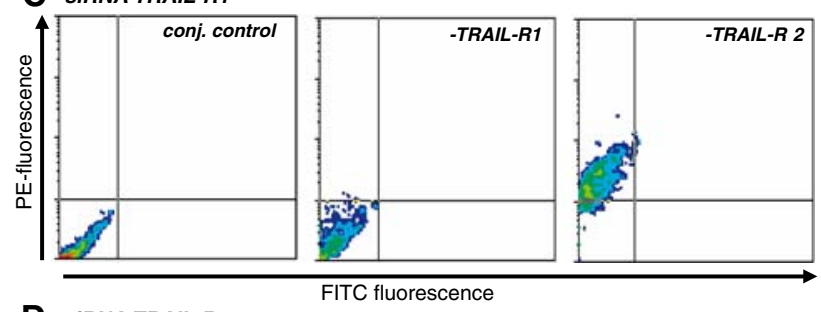

D SIRNA TRAIL-R2

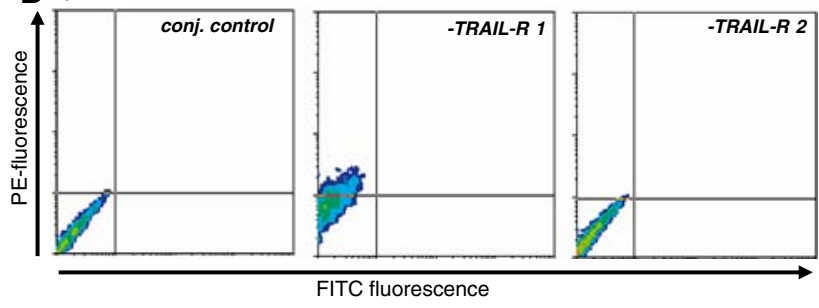

E

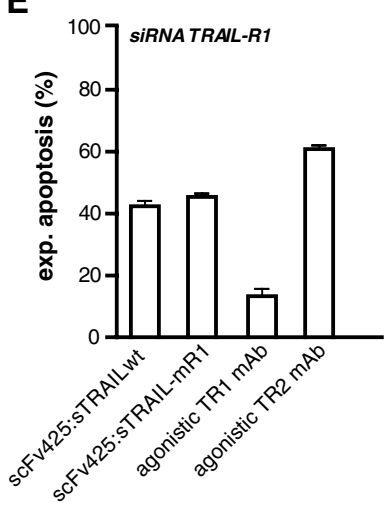

$\mathbf{F}$

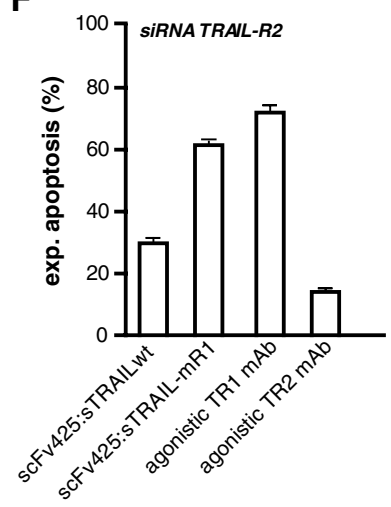

analyzed the NFKB survival signaling as measured by IL-8 production in response to scFv425:sTRAILwt and scFv425:sTRAILmR1-5 treatment in RC21 and PC-3M cells (Fig. 7a). Contrary to expectations, scFv425:sTRAILmR1-5 consistently induced more NFKB signaling than scFv425:sTRAILwt-also in A549, HT-29, and WiDr cells (Fig. 7b). Interestingly, upon immunoblot analysis of p100/p52 and p105/p50 a clear processing of p100 into p52 was detected in scFv425:sTRAILwt but not in scFv425:sTRAILmR1-5 treated cells in both RC21 and PC-3M (Fig. 7c and d), indicating that the fusion proteins activate different subunits of NFKB. To determine the relevance of this observation for the differential apoptotic

Fig. 5 scFv425:sTRAILwt and scFv425:sTRAILmR1-5 activate apoptosis after siRNA-mediated downregulation of TRAIL-R1 or TRAIL-R2. a OVCAR-3 cells were incubated with PE-conjugated Goat-anti-Mouse polyclonal Ab (GaM-PE; solid fill), TRAIL-R1 mAb + GaM-PE (solid line), or TRAIL-R2 mAb + GaM-PE (dotted line), after which TRAIL receptor expression was assessed by flow cytometry as described in "Materials and methods." b OVCAR-3 cells were treated with scFv425:sTRAILwt $(850 \mathrm{ng} / \mathrm{ml})$ or scFv425: sTRAILmR1-5 (850 ng/ml). c. OVCAR-3 cells were treated for $72 \mathrm{~h}$ with TRAIL-R1 siRNA and d. TRAIL-R2 siRNA, after which expression of TRAIL receptors was assessed by incubating cells with TRAIL-R1 mAb and TRAIL-R2 mAb. The depicted histograms are representatives of three independent experiments. e After incubation with TRAIL-R1 siRNA for $72 \mathrm{~h}$, OVCAR-3 cells were treated with scFv425:sTRAILwt, scFv425:sTRAILmR1-5, agonistic TRAIL-R1 $\mathrm{mAb}$, or agonistic TRAIL-R2 mAb. f After incubation with TRAIL-R2 siRNA for $72 \mathrm{~h}$, OVCAR-3 cells were treated with scFv425:sTRAILwt, scFv425:sTRAILmR1-5, agonistic TRAIL-R1 mAb, or agonistic TRAIL-R2 mAb. In all experiments, apoptosis was assessed by $\Delta \Psi$

activity of scFv425:sTRAILwt and scFv425:sTRAILmR1-5, NF $\kappa B$-signaling was inhibited using IKK inhibitor wedelolactone. Unfortunately, cotreatment yielded a similar and marginal increase in apoptosis for both fusion proteins (Fig. 7e and f). Thus, although an intriguing difference in NFKB signaling exists between scFv425:sTRAILwt and scFv425:sTRAILmR1-5, this cannot account for the differential activity of these fusion proteins on PC-3M.

\section{Discussion}

Insight into the contribution of the respective agonistic TRAIL receptors to induction of apoptosis by sTRAIL in selected tumor types may help optimize TRAIL-based therapeutic strategies. The role of TRAIL-R1 in TRAIL signaling in particular is subject to debate. Therefore, we here evaluated the pro-apoptotic activity of fusion protein scFv425:sTRAILmR1-5, comprising EGFR-blocking antibody fragment scFv425 and the previously described TRAIL-R1 selective sTRAIL mutant sTRAILmR1-5 [25]. Fusion protein scFv425:sTRAILmR1-5 showed significantly superior apoptotic activity compared to the corresponding scFv425:sTRAILwt fusion protein on $\sim 60 \%$ of the EGFR-positive solid tumor cell lines tested and showed a nonsignificant trend to higher apoptotic activity on the other cell lines. Both scFv425:sTRAILwt and scFv425:sTRAILmR1-5 showed synergistic pro-apoptotic activity upon cotreatment with cisplatin or the histone deacetylase inhibitor VPA, but scFv425:sTRAILmR1-5 remained significantly more potent when compared to the wild-type sTRAIL fusion protein. Induction of apoptosis by scFv425:sTRAILmR1-5 as well as the synergistic induction of apoptosis with VPA and cisplatin is dependent on binding to EGFR because co-incubation with parental EGFR-blocking mAb 425 strongly inhibits apoptosis. Importantly, compared 
Fig. 6 scFv425:sTRAILwt and scFv425:sTRAILmR1-5 activate similar caspase signaling. Activity of a Caspase-8, b Caspase-9 and c Caspase- 3 or Caspase- 7 was assessed in PC-3M and RC21 cells after incubation for 1 , $2,3,4,5,6$, or $16 \mathrm{~h}$ with either scFv425:sTRAILwt $(850 \mathrm{ng} / \mathrm{ml})$ or scFv425:sTRAILmR1-5 $(850 \mathrm{ng} / \mathrm{ml})$ d. PC-3M cells were treated for $16 \mathrm{~h}$ with scFv425:sTRAILwt (850 ng/ml) or scFv425:sTRAILmR1-5 $(850 \mathrm{ng} / \mathrm{ml})$ in the presence or absence of zIETDFMK $(20 \mu \mathrm{M})$, zLEHD-FMK $(20 \mu \mathrm{M})$, or zVAD-FMK $(20 \mu \mathrm{M})$. Apoptosis was assessed by $\Delta \Psi$. e RC21 and f PC-3M cells were incubated for $6 \mathrm{~h}$ with scFv425:sTRAILwt (850 ng/ml) or scFv425:sTRAILmR1-5 $(850 \mathrm{ng} / \mathrm{ml})$ in the presence or absence of zVAD-FMK $(20 \mu \mathrm{M})$. Whole cell lysates were analyzed for the presence of caspase- 8 and cFLIP $_{\mathrm{L}}$
A

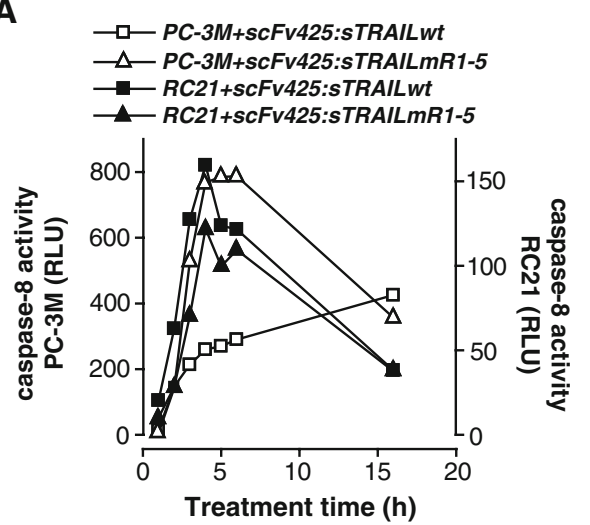

C

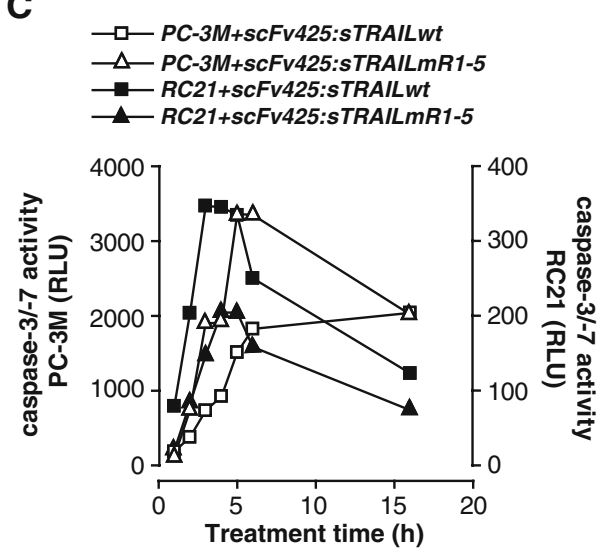

E

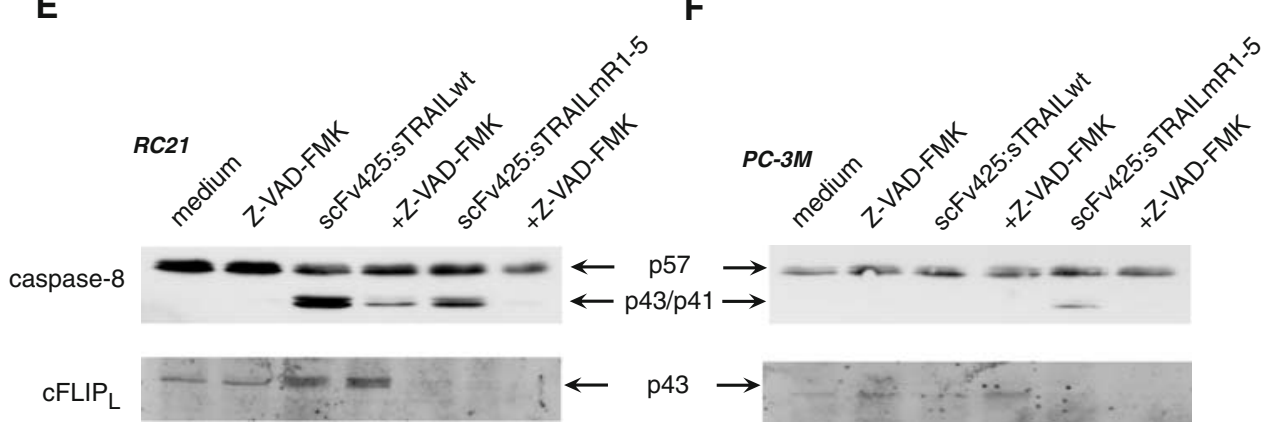

B

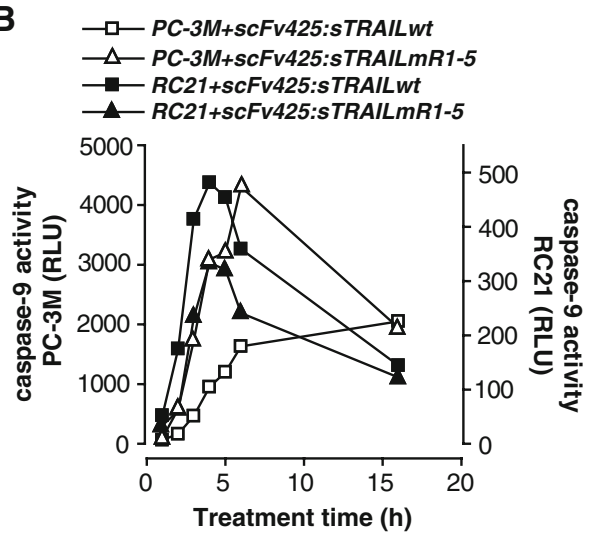

D

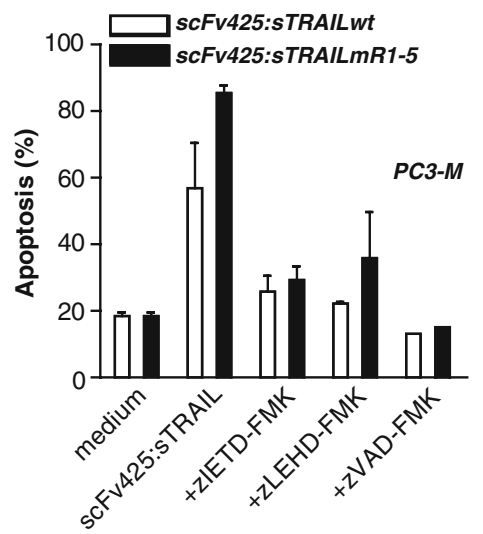

to a nontargeted MOCK-scFv:sTRAILmR1-5 fusion protein directed at the B-cell marker CD20, scFv425:sTRAILmR1-5 showed superior apoptotic activity.

Mutant sTRAILmR1-5 was reported by MacFarlane et al. to be selective for TRAIL-R1. This conclusion was mainly based on the differential apoptotic activity of this mutant towards Jurkat (TRAIL-R1 ${ }^{-}$/TRAIL-R2 ${ }^{+}$) and Ramos cells (TRAIL-R1 ${ }^{+} /$TRAIL-R2 ${ }^{+}$) [24]. However, our experiments collectively demonstrate that sTRAILmR1-5 is actually not selective for TRAIL-R1. In ELISA experiments, scFv425:sTRAILmR1-5 bound to TRAIL-R2:Fc in a catching-type ELISA. Furthermore, binding of scFv425:sTRAILmR1-5 to TRAIL-R1:Fc was competitively inhibited by addition of soluble TRAIL-R2:Fc. Interestingly, TRAIL-R1:Fc was superior to TRAIL-R2:Fc in inhibiting
scFv425:sTRAILmR1-5, whereas the reverse was true for scFv425:sTRAILwt, indicating a reversal in affinity between sTRAIL-wt and the sTRAILmR1-5 domain for TRAIL-R1 and TRAIL-R2. Of note, the only interaction that is being investigated in these ELISAs is that of the sTRAIL domain with TRAIL receptors. Thus, these experiments demonstrate that the sTRAILmR1-5 domain in itself is capable of binding to TRAIL-R2.

The binding of the sTRAILmR1-5 domain to TRAILR2 also has functional implications because induction of apoptosis by scFv425:sTRAILmR1-5 was markedly inhibited by a TRAIL-R2 blocking antibody. In actual fact, the TRAIL-R2 blocking $\mathrm{mAb}$ was more effective than the TRAIL-R1 blocking mAb. Moreover, 92\% downregulation of TRAIL-R1 by small inhibitory RNA did not 
Fig. 7 The differential activity of scFv425:sTRAILwt and scFv425:sTRAILmR1-5 is not due to NFKB signalling. a RC21, PC-3M and b A549, HT29, and WiDr cells were incubated for $16 \mathrm{~h}$ with scFv425:sTRAILwt $(850 \mathrm{ng} / \mathrm{ml})$ or scFv425:sTRAILmR1-5 $(850 \mathrm{ng} / \mathrm{ml})$ in the presence or absence of zVAD-FMK

$(20 \mu \mathrm{M})$, after which, supernatant was analyzed for IL-8 levels. c RC21 and d PC-3M cells were incubated in the presence or absence of zVAD-FMK $(20 \mu \mathrm{M})$. Whole cell lysates were analyzed for the presence of NF $\kappa B$ subunits $\mathrm{p} 100 / \mathrm{p} 52$, $\mathrm{p} 105 / \mathrm{p} 50$, and $\mathrm{p} 65$. e RC21 and f PC-3M cells were treated for $6 \mathrm{~h}$ with scFv425:sTRAILwt $(850 \mathrm{ng} / \mathrm{ml})$ or scFv425:sTRAILmR1-5 $(850 \mathrm{ng} / \mathrm{ml})$ in the presence of IKK inhibitor wedelolactone. Apoptosis was assessed by DY
A

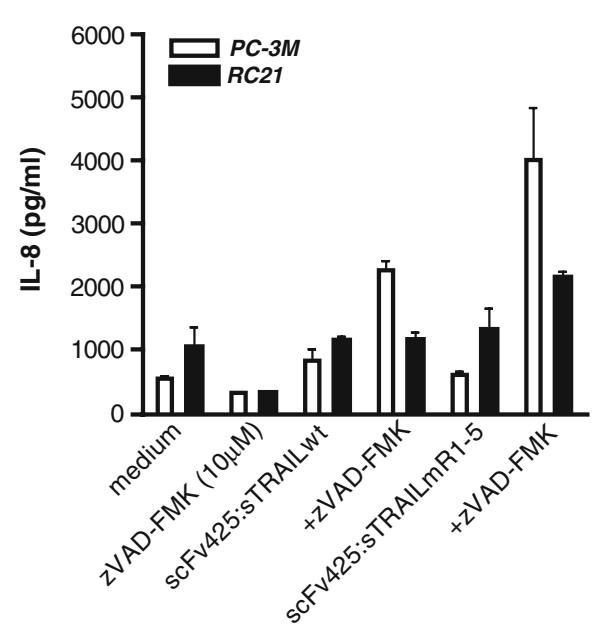

C
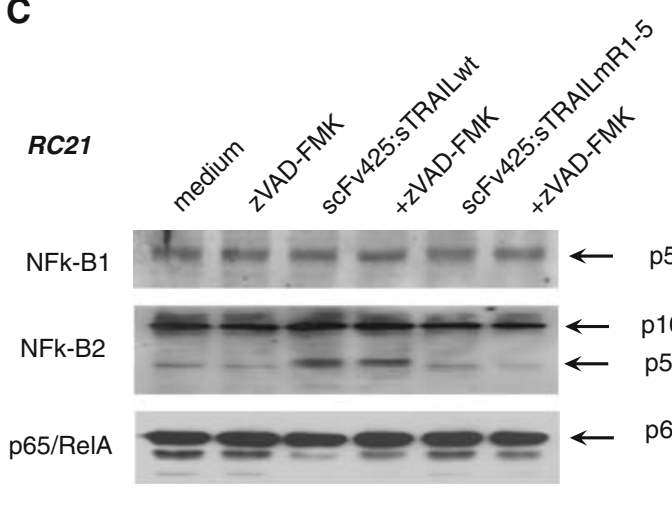

$\mathbf{E}$

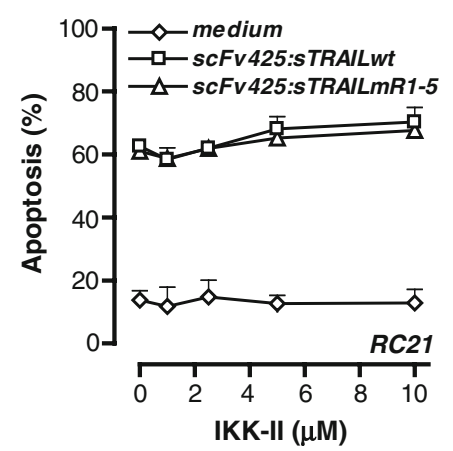

B

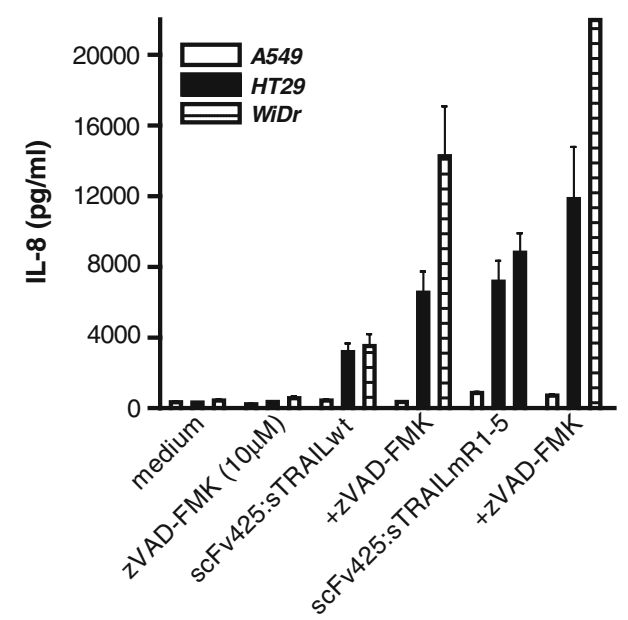

D

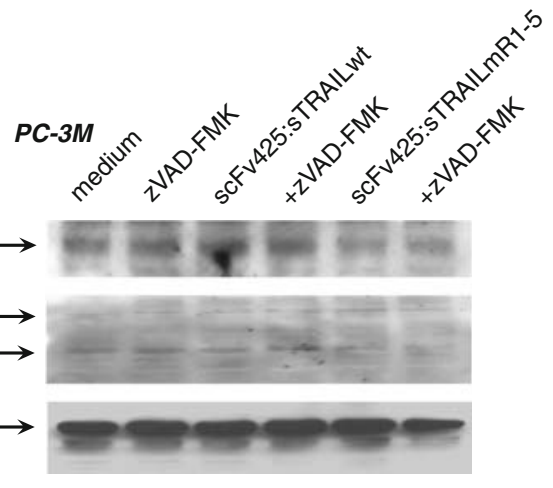

$\mathbf{F}$

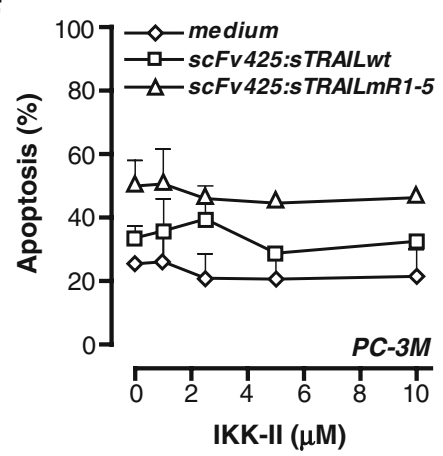

abrogate the apoptotic activity of scFv425:sTRAILmR1-5. Indeed some of the more sensitive cell lines actually have very low TRAIL-R1 expression (Table 2). Collectively, these data indicate that target antigen-bound scFv425:sTRAILmR1-5 is capable of binding to and activating TRAIL-R2. Therefore, our data also warrant a re-evaluation of the conclusion of MacFarlane et al. that nontargeted sTRAILmR1-5 is selective for TRAIL-R1.

Interestingly, induction of apoptosis by $\mathrm{scFv} 425$ : sTRAILmR1-5 fusion protein was more effectively inhibited by TRAIL-R blocking mAbs than the induction of apoptosis by scFv425:sTRAILwt or kTRAIL. These experiments suggest that the wild-type sTRAIL domain has a relatively higher affinity for its receptors and can, thus, more efficiently compete with the TRAIL-R blocking mAbs for binding to the receptors. Together, this also implies that, while en route to the tumor, scFv425:sTRAILmR1-5 will display a more transient binding to the ubiquitously expressed TRAIL receptors. As a result, tumor cell accretion is expected to be more efficient for scFv425:sTRAILmR1-5 compared to scFv425:sTRAILwt.

Our experimental data regarding the activity of scFv425:sTRAILmR1-5 also highlight an intriguing question, namely: what is the molecular mechanism for the 
enhanced activity of this sTRAIL mutant on EGFRpositive tumor cell lines as reported here and on primary patient-derived B-cell chronic lymphoid leukemia (BCLL) cells as reported previously. First and foremost, based on our experimental evidence, it is obvious that both TRAIL-R1 and TRAIL-R2 signaling are an integral part of the apoptotic activity of this mutant. However, there is no obvious correlation between the apoptotic activity of scFv425:sTRAILmR1-5 and the expression levels of the respective TRAIL receptors, nor the ratios of the various TRAIL receptors (TRAIL-R2/TRAIL-R1, TRAIL-R1/TRAIL-R4, and TRAIL-R2/TRAIL-R4).

One possible explanation for our and MacFarlane's observations may be found in the incompletely characterized complexity of TRAIL receptor biology. Several groups have found experimental evidence that TRAIL receptors cannot only exist in a homotrimeric form but can also form heterotrimeric complexes comprising TRAIL-R1 and TRAIL-R2 monomers [28, 29]. As such, TRAIL-R1 or TRAIL-R2 heterotrimers may represent nature's strategy to fine tune the apoptotic response to TRAIL.

It is tempting to speculate that sTRAILmR $1-5$, besides activating homotrimeric TRAIL-R1, may be better able to activate TRAIL-R1 or TRAIL-R2 heterotrimers than wildtype sTRAIL. Such a differential capacity to activate heterotrimers might explain the superior induction of apoptosis by scFv425:sTRAILmR1-5 in a subset of cell lines. This hypothesis is in line with most of our observations, including the finding that scFv425:sTRAILmR1-5 is inactive on A2780 cells that only express TRAIL-R2 (data not shown), while induction of apoptosis by scFv425:sTRAILmR1-5 is potently inhibited by a TRAIL-R2 blocking antibody on TRAIL-R1 $^{+} /$TRAIL-R2 $^{+}$cells. Moreover, siRNA knockdown of either TRAIL-R1 or TRAIL-R 2 by $>90 \%$ does not block induction of apoptosis by scFv425:sTRAILmR1-5.

Further circumstantial evidence for heterotrimeric TRAIL-R1 or TRAIL-R2 can be found in a recent report in which it was shown that selective activation of either TRAIL-R1 or TRAIL-R2 with receptor specific agonistic mAbs in B-CLL cells is not as effective as sTRAIL-mediated apoptosis of the same cells [30]. These results point to a benefit of simultaneous triggering of both TRAIL receptors. Interestingly, sTRAIL versions such as Apo2L or sTRAIL (Genentech) that activate apoptosis predominantly through TRAIL-R2 were less efficacious than those versions that also signal apoptosis via TRAIL-R1, which is in agreement with our finding that scFv425:sTRAILmR1-5 is more active than scFv425:sTRAILwt.

An alternative or complementary hypothesis for the enhanced activity of scFv425:sTRAILmR1-5 may be found in the recently described potential for S-nitrosylation of TRAIL-R1 and not TRAIL-R2 [31]. Tang et al. found that treatment of OVCAR-3 cells with a nitric oxide donor resulted in the S-nitrosylation of TRAIL-R1 at cysteine residue 336, with a concomitant superior induction of apoptosis by TRAIL. Therefore, the presence of S-nitrosylated TRAIL-R1 in certain cell lines, intrinsically subject to higher nitric oxide stress, may account for the superior apoptotic activity of scFv425:sTRAILmR1-5.

Importantly, the superior apoptotic activity of scFv425:sTRAILmR1-5 on certain cell lines is not related to Phosphoinositide 3-kinase signaling, C-Jun Nterminal kinases signaling (data not shown), nor on differential caspase signaling or NFKB signaling. However, independent of the differential apoptotic activity of scFv425:sTRAILwt and scFv425:sTRAILmR1-5, we observed an intriguing difference in the level of $\mathrm{cFLIP}_{\mathrm{L}}$ in treated cells. Treatment with scFv425:sTRAILwt was associated with an increased level of $\mathrm{cFLIP}_{\mathrm{L}}$, whereas scFv425:sTRAILmR1-5 treated cells lacked $\mathrm{cFLIP}_{\mathrm{L}}$ expression altogether. At the same time, scFv425:sTRAILmR1-5 treated cells showed increased levels of NFKB activation, as judged by IL- 8 production. Therefore, although $\mathrm{cFLIP}_{\mathrm{L}}$ has been predominantly described as a constitutive activator of NFKB signaling, our data actually highlight a potential opposite correlation, with loss of $\mathrm{cFLIP}_{\mathrm{L}}$ occurring concurrently with higher NFKB activity. This finding is in agreement with a previous report by Wajant et al. who also demonstrated an inhibitory role of $\mathrm{cFLIP}_{\mathrm{L}}$. A further intriguing finding regarding the $N F \kappa B$ pathway is the differential processing of the pro-units p100 into p 52 by scFv425:sTRAILwt but not by scFv425:sTRAILmR1-5. Although puzzling, our data highlight the very complex relationship between TRAIL receptor signaling and NFKB activation.

Of note, mutant sTRAILmR1-5 is a derivative of another designed TRAIL-R1 selective sTRAIL mutant, sTRAILmR1-6, that was generated by Kelley et al. [23]. Based partly on mutant sTRAILmR1-6, Kelley et al. ascribed a greater role for TRAIL-R2 in TRAIL-apoptotic signaling in solid tumors. Because this mutant was later found to be inactive and we here clearly demonstrate TRAIL-R1 signaling in solid tumor cells, the conclusions of Kelley et al. that TRAIL-R1 is not important in solid tumors may need to be revised.

Although homotrimeric wild-type sTRAIL is widely regarded as nontoxic toward normal human cells, an important issue to consider in the use of mutated versions of sTRAIL, such as sTRAILmR1-5, is the potential presence of toxicity resulting from the incorporated amino acid mutations. A future in depth toxicological evaluation in primary human cells and in appropriate animal models will be required to accurately assess the toxicity profile, and thus the therapeutic potential, of scFv425:sTRAILmR1-5.

In conclusion, the EGFR-specific delivery of mutant sTRAILmR1-5 results in superior apoptotic activity to- 
wards EGFR-positive tumor cells. Further preclinical development of scFv425:sTRAILmR1-5 appears warranted to determine the therapeutic potential of this fusion protein for the treatment of EGFR-positive tumors.

Open Access This article is distributed under the terms of the Creative Commons Attribution Noncommercial License which permits any noncommercial use, distribution, and reproduction in any medium, provided the original author(s) and source are credited.

\section{References}

1. Smyth M, Cretney E, Takeda K, Wiltrout R, Sedger L, Kayagaki N, Yagita H, Okumura K (2001) Tumor Necrosis Factor-related Apoptosis-inducing Ligand (TRAIL) contributes to interferon $\{\{$ gamma $\}$-dependent natural killer cell protection from tumor metastasis. J Exp Med 6:661-670

2. Takeda K, Hayakawa Y, Smyth M, Kayagaki N, Yamaguchi N, Kakuta S, Iwakura Y, Yagita H, Okumura K (2001) Involvement of tumor necrosis factor-related apoptosis-inducing ligand in surveillance of tumor metastasis by liver natural killer cells. Nat Med 1:94-100

3. Wiley SR, Schooley K, Smolak PJ, Din WS, Huang CP, Nicholl JK, Sutherland GR, Smith TD, Rauch C, Smith CA (1995) Identification and characterization of a new member of the TNF family that induces apoptosis. Immunity 6:673-682

4. Pitti R, Marsters S, Ruppert S, Donahue C, Moore A, Ashkenazi A (1996) Induction of apoptosis by apo-2 ligand, a new member of the tumor necrosis factor cytokine family. J Biol Chem 22:12687-12690

5. Walczak H, Miller R, Ariail K, Gliniak B, Griffith T, Kubin M, Chin W, Jones J, Woodward A, Le T, Smith C, Smolak P, Goodwin R, Rauch C, Schuh J, Lynch D (1999) Tumoricidal activity of tumor necrosis factor-related apoptosis-inducing ligand in vivo. Nat Med 2:157-163

6. Roth W, Isenmann S, Naumann U, Kugler S, Bahr M, Dichgans J, Ashkenazi A, Weller M (1999) Locoregional Apo2L/TRAIL eradicates intracranial human malignant glioma xenografts in athymic mice in the absence of neurotoxicity. Biochem Biophys Res Commun 2:479-483

7. Ashkenazi A, Pai RC, Fong S, Leung S, Lawrence DA, Marsters SA, Blackie C, Chang L, McMurtrey AE, Hebert A, DeForge L, Koumenis IL, Lewis D, Harris L, Bussiere J, Koeppen H, Shahrokh Z, Schwall RH (1999) Safety and antitumor activity of recombinant soluble Apo2 ligand. J Clin Invest 2:155-162

8. Wajant H, Moosmayer D, Wuest T, Bartke T, Gerlach E, Schonherr U, Peters N, Scheurich P, Pfizenmaier K (2001) Differential activation of TRAIL-R1 and -2 by soluble and membrane TRAIL allows selective surface antigen-directed activation of TRAIL-R 2 by a soluble TRAIL derivative. Oncogene 30:4101-4106

9. Bremer E, Samplonius DF, Peipp M, van Genne L, Kroesen BJ, Fey GH, Gramatzki M, de Leij LF, Helfrich W (2005) Target cell-restricted apoptosis induction of acute leukemic $\mathrm{T}$ cells by a recombinant tumor necrosis factor-related apoptosis-inducing ligand fusion protein with specificity for human CD7. Cancer Res 8:3380-3388

10. Bremer E, Samplonius DF, van Genne L, Dijkstra MH, Kroesen BJ, de Leij LF, Helfrich W (2005) Simultaneous inhibition of epidermal growth factor receptor (EGFR) signaling and enhanced activation of tumor necrosis factor-related apoptosis-inducing ligand (TRAIL) receptor-mediated apoptosis induction by an scFv:sTRAIL fusion protein with specificity for human EGFR. J Biol Chem 11:10025-10033
11. Bremer E, Samplonius D, Kroesen BJ, van Genne L, de Leij L, Helfrich W (2004) Exceptionally potent anti-tumor bystander activity of an scFv:sTRAIL fusion protein with specificity for EGP2 toward target antigen-negative tumor cells. Neoplasia 5:636-645

12. Bremer E, Kuijlen J, Samplonius D, Walczak H, de Leij L, Helfrich W (2004) Target cell-restricted and -enhanced apoptosis induction by a scFv:sTRAIL fusion protein with specificity for the pancarcinoma-associated antigen EGP2. Int J Cancer 2:281-290

13. Pan G, O’Rourke K, Chinnaiyan AM, Gentz R, Ebner R, Ni J, Dixit VM (1997) The receptor for the cytotoxic ligand TRAIL. Science 276:111-113

14. Pan G, Ni J, Wei Y, Yu G, Gentz R, Dixit V (1997) An antagonist decoy receptor and a death domain-containing receptor for TRAIL. Science 5327:815-818

15. Walczak H, Degli-Esposti MA, Johnson RS, Smolak PJ, Waugh JY, Boiani N, Timour MS, Gerhart MJ, Schooley KA, Smith CA, Goodwin RG, Rauch CT (1997) TRAIL-R2: a novel apoptosismediating receptor for TRAIL. EMBO J 17:5386-5397

16. Degli-Esposti MA, Smolak PJ, Walczak H, Waugh J, Huang CP, DuBose RF, Goodwin RG, Smith CA (1997) Cloning and characterization of TRAIL-R3, a novel member of the emerging TRAIL receptor family. J Exp Med 7:1165-1170

17. Mongkolsapaya J, Cowper AE, Xu XN, Morris G, McMichael AJ, Bell JI, Screaton GR (1998) Lymphocyte inhibitor of TRAIL (TNF-related apoptosis-inducing ligand): a new receptor protecting lymphocytes from the death ligand TRAIL. J Immunol 1:3-6

18. Degli-Esposti MA, Dougall WC, Smolak PJ, Waugh JY, Smith CA, Goodwin RG (1997) The novel receptor TRAIL-R4 induces NF-kappaB and protects against TRAIL-mediated apoptosis, yet retains an incomplete death domain. Immunity 6:813-820

19. Marsters SA, Sheridan JP, Pitti RM, Huang A, Skubatch M, Baldwin D, Yuan J, Gurney A, Goddard AD, Godowski P, Ashkenazi A (1997) A novel receptor for Apo2L/TRAIL contains a truncated death domain. Curr Biol 12:1003-1006

20. Pan G, Ni J, Yu G, Wei YF, Dixit VM (1998) TRUNDD, a new member of the TRAIL receptor family that antagonizes TRAIL signalling. FEBS Lett 1-2:41-45

21. Emery JG, McDonnell P, Burke MB, Deen KC, Lyn S, Silverman C, Dul E, Appelbaum ER, Eichman C, DiPrinzio R, Dodds RA, James IE, Rosenberg M, Lee JC, Young PR (1998) Osteoprotegerin is a receptor for the cytotoxic ligand TRAIL. J Biol Chem 23:14363-14367

22. Koschny R, Walczak H, Ganten TM (2007) The promise of TRAIL-potential and risks of a novel anticancer therapy. J Mol Med 9:923-935

23. Kelley R, Totpal K, Lindstrom S, Mathieu M, Billeci K, DeForge L, Pai R, Hymowitz S, Ashkenazi A (2005) Receptor-selective mutants of apoptosis-inducing ligand $2 /$ tumor necrosis factorrelated apoptosis-inducing ligand reveal a greater contribution of death receptor (DR) 5 than DR4 to apoptosis signaling. J Biol Chem 3:2205-2212

24. van der Sloot A, Tur V, Szegezdi E, Mullally M, Cool R, Samali A, Serrano L, Quax W (2006) Designed tumor necrosis factorrelated apoptosis-inducing ligand variants initiating apoptosis exclusively via the DR5 receptor. PNAS 23:8634-8639

25. MacFarlane M, Kohlhaas S, Sutcliffe M, Dyer M, Cohen G (2005) TRAIL receptor-selective mutants signal to apoptosis via TRAIL-R1 in primary lymphoid malignancies. Cancer Res 24:11265-11270

26. Muller KM, Arndt KM, Pluckthun A (1998) A dimeric bispecific miniantibody combines two specificities with avidity. FEBS Lett $1-2: 45-49$

27. Cockett MI, Bebbington CR, Yarranton GT (1990) High level expression of tissue inhibitor of metalloproteinases in Chinese hamster ovary cells using glutamine synthetase gene amplification. Biotechnology (N Y) 7:662-667

28. Kischkel F, Lawrence D, Chuntharapai A, Schow P, Kim KJ, Ashkenazi A (2000) Apo2L/TRAIL-dependent recruitment of 
endogenous FADD and caspase-8 to death receptors 4 and 5 . Immunity 6:611-620

29. Clancy L, Mruk K, Archer K, Woelfel M, Mongkolsapaya J, Screaton G, Lenardo M, Chan F (2005) Preligand assembly domain-mediated ligand-independent association between TRAIL receptor 4 (TR4) and TR2 regulates TRAIL-induced apoptosis6. PNAS 50:18099-18104
30. MacFarlane $\mathrm{M}$, Inoue $\mathrm{S}$, Kohlhaas SL, Majid A, Harper N, Kennedy DBJ, Dyer MJS, Cohen GM (2005) Chronic lymphocytic leukemic cells exhibit apoptotic signaling via TRAIL-R1. Cell Death Differ 7:773-782

31. Tang Z, Bauer JA, Morrison B, Lindner DJ (2006) Nitrosylcobalamin promotes cell death via $S$ nitrosylation of Apo2L/TRAIL receptor DR4. Mol Cell Biol 15:5588-5594 